University of Wollongong

Research Online

Faculty of Business - Papers (Archive)

Faculty of Business and Law

$1-1-2014$

Reframing success and failure of information systems: a performative perspective

Dubravka Cecez-Kecmanovic

University of New South Wales

Karlheinz Kautz

University of Wollongong, karlheinz.kautz@rmit.edu.au

Rebecca Abrahall

University of New South Wales

Follow this and additional works at: https://ro.uow.edu.au/buspapers

Part of the Business Commons

Research Online is the open access institutional repository for the University of Wollongong. For further information contact the UOW Library: research-pubs@uow.edu.au 


\title{
Reframing success and failure of information systems: a performative perspective
}

\begin{abstract}
The paper questions common assumptions in the dominant representational framings of information systems success and failure and proposes a performative perspective that conceives IS success and failure as relational effects performed by sociomaterial practices of IS project actor-networks of developers, managers, technologies, project documents, methodologies, and other actors. Drawing from a controversial case of a highly innovative information system in an insurance company-considered a success and failure at the same time- the paper reveals the inherent indeterminacy of IS success and failure and describes the mechanisms by which success and failure become performed and thus determined by sociomaterial practices. This is explained by exposing ontological politics in the reconfiguration and decomposition of the IS project actor-network and the emergence of different agencies of assessment that performed both different IS realities and competing IS assessments. The analysis shows that the IS project and the implemented system as objects of assessment are not given and fixed, but are performed by the agencies of assessment together with the assessment outcomes of success and failure. The paper demonstrates that by reframing IS success and failure, the performative perspective provides some novel and surprising insights that have a potential to change conversations on IS assessments in both the IS literature and IS practice.
\end{abstract}

\section{Keywords}

failure, reframing, perspective, success, performative, systems, information

\section{Disciplines}

Business

\section{Publication Details}

Cecez-Kecmanovic, D., Kautz, K. \& Abrahall, R. (2014). Reframing success and failure of information systems: a performative perspective. MIS Quarterly, 38 (2), 561-588. 


\title{
REFRAMING SUCCESS AND FAILURE OF INFORMATION SYStems: A Performative PeRspective ${ }^{1}$
}

\author{
Dubravka Cecez-Kecmanovic \\ School of Information Systems, Technology and Management, Australian School of Business, \\ University of New South Wales, Sydney, NSW 2052, AUSTRALIA \{dubravka@unsw.edu.au\} \\ Karlheinz Kautz \\ School of Management, Operations and Marketing, Faculty of Business, University of Wollongong, \\ Northfields Avenue, Wollongong, NSW 2522, AUSTRALIA \{kautz@uow.edu.au\}

\section{Rebecca Abrahall} \\ School of Information Systems, Technology and Management, Australian School of Business, \\ University of New South Wales, Sydney, NSW 2052, AUSTRALIA \{becky.abrahall@gmail.com\}
}

\begin{abstract}
The paper questions common assumptions in the dominant representational framings of information systems success and failure and proposes a performative perspective that conceives IS success and failure as relational effects performed by sociomaterial practices of IS project actor-networks of developers, managers, technologies, project documents, methodologies, and other actors. Drawing from a controversial case of a highly innovative information system in an insurance company — considered a success and failure at the same timethe paper reveals the inherent indeterminacy of IS success and failure and describes the mechanisms by which success and failure become performed and thus determined by sociomaterial practices. This is explained by exposing ontological politics in the reconfiguration and decomposition of the IS project actor-network and the emergence of different agencies of assessment that performed both different IS realities and competing IS assessments. The analysis shows that the IS project and the implemented system as objects of assessment are not given and fixed, but are performed by the agencies of assessment together with the assessment outcomes of success and failure. The paper demonstrates that by reframing IS success and failure, the performative perspective provides some novel and surprising insights that have a potential to change conversations on IS assessments in both the IS literature and IS practice.
\end{abstract}

Keywords: IS project success and failure, IS success and failure, IS project assessment, IS benefits assessment, sociomaterial worldview, performative perspective, actor-network theory (ANT), ontological politics, agency of assessment

\footnotetext{
${ }^{1}$ Ola Henfridsson was the accepting senior editor for this paper. Mike Chiasson served as the associate editor.
} 


\section{Introduction}

The failure rate of information systems (IS) development and implementation projects has not changed much in the last $30+$ years, remaining worryingly high at around 70 percent, depending on the source (Doherty et al. 2011). The disappointing failure rates of IS projects and the uncertainty of value realization through systems use are still troubling practitioners and puzzling researchers (Bloch et al. 2012; Doherty et al. 2011; Remus and Wiener 2010; Urbach et al. 2008). A substantial body of IS literature has proposed and tested a list of both technological and organizational factors that should assist organizations in successfully completing the projects and delivering the expected benefits (El Emam and Koru 2008; Petter et al. 2008; Sabherwal et al. 2006). However, given the persistence of such high failure rates, it appears that substantial accumulated knowledge has not made a difference in IS practice (Cobb 1996; Doherty et al. 2011). This proposition, on the other hand, seems somewhat inconsistent with the evidence from the recent survey by McKinsey \& Company (2011) that companies worldwide are increasing their IS investments and also their expectations for information systems to support innovation and growth.

This inconsistency might be partly attributed to the dominant framings of IS success and, by implication, failure that underpin our empirical studies. It is generally assumed that an IS project is considered successful if it delivers a working system "on time, on budget and to specifications" (Doherty et al. 2011, p. 2; see also Sauer and Davis 2010). The success of an IS project is assessed using these simple measures, perceived as objective, rational, and fact-based: projects do indeed deliver either on time, on budget, and to specifications or not. Such assessment, however, ignores the unavoidable uncertainty in determining and predicting the time required and the budget needed for the development of a system defined by its specifications (information requirements). Furthermore, specifications are likely to change during the development and even after the system is implemented (Holmström and Sawyer 2011; Truex et al. 1999). Another prescription from the literature that a successful IS implementation "delivers benefits that exceed the costs of achieving them" has also been questioned (Doherty et al. 2011, p. 2). Benefits take time to realize. Whether an information system would be considered a success or not is contingent upon the calculation of benefits, tangible and intangible, and the time allowed for benefits to materialize. What is remarkable in the assessment of both IS projects and implemented systems is the use of simple and seemingly objective measures to represent their success despite the uncertainty and arbitrariness involved in such representations.

Other prominent approaches in the literature have assumed that there is no objectively correct account of success/failure and that the assessment outcomes (measures) do not exist irrespective of the actors, stakeholders with differing views and often conflicting interests. Theoretically diverse research opens up a wider field of inquiry by framing IS success as subjective interpretations, narratives, and social constructions resulting from often complex and contested social and political processes, in specific organizational contexts (Bartis and Mitev 2008; Briggs et al. 2003; Fincham 2002; Jones and Hughes 2001; Sauer 1993; Smithson and Tsiavos 2004; Walsham 1999; Wilson and Howcroft 2005). For instance, the interpretive flexibility of an information system explains how different social groups attribute different meanings and construct different narratives of an IS success or failure (Bartis and Mitev 2008; Fincham 2002). Importantly, different meanings, interpretations, narratives, and political negotiations are also particular representations of IS success by different social groups. While we learned a great deal about IS assessment processes, these studies tended to emphasize the role and agency of social actors in determining success and to downplay the role of the very objects of assessment: information systems and IS projects.

As this brief discussion suggests, the framings of IS success in the literature are representational in nature. In other words, IS success is represented either by objective measures or by subjective perceptions of social actors. The problem with representationalism, as science studies scholars have long argued, is the assumption that representations and the objects they represent are independently existing entities (Barad 2003, 2007; Rouse 1996). That is, assessments of IS success as facts or perceptions exist as entities separate from IS as objects of assessment. What is particularly striking is the faith in representations, either as measures or subjective interpretations of IS success, as opposed to that which is represented. What seems to be hidden from view is that IS projects and implemented systems as objects of assessment are not given and fixed but are themselves performed as objects by the processes of assessments.

The aim of this paper is to propose a performative perspective on IS success as an alternative to representational modes of framing, and to show how it advances knowledge and enables novel insights into the phenomena of IS assessments. Founded on a sociomaterial worldview (Barad 2003, 2007; Orlikowski 2010), the performative perspective draws attention to sociomaterial practices in IS project actor-networks defined as configurations of IS developers, managers, technologies, project documents, methodologies, and other actors. It is IS project actor-networks within which project objectives, time lines, and resources are negotiated and projects and their assessments performed (Law and Callon 1997; McMaster and Wastell 2005). The performative perspective reveals the ways in which these actor-networks give rise to different agencies of assessment that perform different IS 
assessments, as well as information systems. The performative perspective provides a conceptual apparatus for examining local reconfigurations of IS project actor-networks involving shifting sociomaterial practices and production of IS assessments, thus allowing us to examine a key question: How do different and potentially competing assessments of an information system and an IS project arise from different sociomaterial practices?

We explore this question by drawing from the case study of a project that delivered a highly innovative information system in an insurance company, which was fraught with controversy. While the IS implementation was highly praised and considered a success by the users (insurance brokers, who as intermediaries sell these products to clients), both the system and the project were considered a failure by key managers of the organization. By following the IS project from its inception and by examining the production of competing assessments from the performative perspective, we show how an inherently indeterminate IS success becomes locally determinable and thus seen as determinate in different sociomaterial practices. The paper demonstrates how the performative framing extends the body of knowledge on IS success and also opens a conceptual space for seeing how existing framings are produced and taken for granted.

We develop our argument by first reviewing existing framings of IS success and their underlying assumptions. We then introduce the performative perspective and its key assumptions based on a sociomaterial theoretical foundation. This is followed by a description of the research methodology, the adoption of actor-network theory (ANT) and a brief story of the case company and its IS development, implementation, and assessment. Based on the ANT study of the reconfigurations of the IS project actor-network, the discussion focuses on the ways the information system was enacted in different sociomaterial practices and the mechanisms by which these different enactments created multiple and competing realities of IS success and failure. The paper concludes by summarizing the theoretical and potential practical contributions of the performative perspective on IS success and some novel research questions raised by it.

\section{Literature Review and Theoretical Background}

\section{Representational Framings of IS Success}

Definitions of IS project and system success and failure in the literature are in abundance (Doherty et al. 2011; EwusiMensah and Przasnyski 1994; Fincham 2002; Lee and Xia 2005; Lyytinen and Hirschheim 1987; Sauer 1993). Widely adopted and still relevant is Lyytinen and Hirschheim's (1987) classification of failures as (1) an IS correspondence failure when a system does not meet the predefined set of objectives (a system is either abandoned or scaled down), (2) an IS process failure that denotes unsatisfactory development performance that does not deliver a functioning system or runs over time and over budget, (3) an IS interaction failure defined as users' dissatisfaction with or poor usage of a system, and (4) an IS expectation failure indicating inability of the information system to fulfill stakeholders' needs, expectations, and interests. Such views of IS failure are representational as they assume the existence of certain properties or factors that determine failure. IS success is defined as a mirror image of IS failure.

The representational view of IS success is widespread in the literature irrespective of the differences in research approaches and perspectives. This can be seen by examining the literature broadly clustered around the objective/rational and the subjective/political perspectives, which were initially defined by Hirschheim and Smithson (1988) and later adopted by Introna and Whittaker (2003). While founded on different ontological and epistemological assumptions both perspectives on IS success show their representational nature as summarized in Table 1.

Underlying the objective/rational perspective is an ontological assumption that an IS project success or failure exists as a discrete and determinate state, and an epistemological assumption that success and failure can be determined and objectively measured. It is further assumed that measures or criteria for assessment are rational and neutral and thus produce objective assessments, irrespective of the assessor (Introna and Whittaker 2003). Similarly, it is assumed that success and failure of an information system implemented and used exist out there, determined by the system's properties or factors such as information quality, system quality, and service quality; satisfaction with the information system and realization of expectations; and performance and functionality according to specifications and predefined objectives (Doherty et al. 2011). In the assessment process, both information systems and IS projects are considered passive and neutral objects of assessment whose properties, performances, and benefits are objectively represented and measured using various criteria.

Such a representational view led researchers to examine whether information systems and IS projects that succeeded have certain characteristics that are significantly different from those that failed. Researchers, therefore, have surveyed organizations to find out which characteristics or factors are associated with success and which ones with failure. It was found, for instance, that numerous organizational and social 
Table 1. Representational Nature of Different Framings of IS Success and Failure in the Literature

\begin{tabular}{|c|c|c|}
\hline & \multicolumn{2}{|c|}{ Framings of Success and Failure } \\
\hline & Objective/Rational & Subjective/Political \\
\hline $\begin{array}{l}\text { IS project as } \\
\text { an object of } \\
\text { assessment }\end{array}$ & $\begin{array}{l}\text { An IS project success/failure exists as discrete } \\
\text { and determinate states that can be objectively } \\
\text { measured and represented. } \\
\text { An IS project success is measured typically by } \\
\text { project completion on time and on budget and the } \\
\text { delivery of IS (an IT artefact) according to } \\
\text { specifications. } \\
\text { An IS project as an object of assessment is objec- } \\
\text { tively represented and assessed by rational and } \\
\text { neutral measures thus making the assessment } \\
\text { independent of the assessor. } \\
\text { Research has found a range of factors causally } \\
\text { linked to IS project success/failure: } \\
\text { - Senior management commitment and support } \\
\text { - Active user participation } \\
\text { - Business planning and project planning } \\
\text { - Clear project goals and specifications of the IT } \\
\text { artefact } \\
\text { - Effective project management and control } \\
\text { - Culture, leadership and management issues } \\
\text { - Appropriate staff training } \\
\text { - Appropriate expertise and capability of IT/IS } \\
\text { professionals }\end{array}$ & $\begin{array}{l}\text { An IS project success/failure does not exist out there } \\
\text { but results from processes of sensemaking and } \\
\text { interpretation, organizational discourses and political } \\
\text { negotiations within particular socio-cultural and } \\
\text { political contexts. } \\
\text { An IS project success/failure is thus represented as } \\
\text { narratives, interpretations and discourses by different } \\
\text { stakeholders and social groups; as they typically } \\
\text { have different values, interests, interpretive schemes } \\
\text { and information needs they do not agree about IS } \\
\text { project assessments or what constitutes a success or } \\
\text { failure. } \\
\text { Research contributed to understand how particular } \\
\text { interpretations and narratives of IS project success/ } \\
\text { failure emerge within dynamic organizational, social } \\
\text { and political contexts. } \\
\text { The assessments of IS projects are found to be } \\
\text { changing as episodes of success and failure emerge } \\
\text { within unfolding projects; research also found that IS } \\
\text { project success often depends on stakeholders and } \\
\text { the timing of assessment and is thus seen as } \\
\text { politically motivated, subjective and arbitrary. }\end{array}$ \\
\hline $\begin{array}{l}\text { Information } \\
\text { System as } \\
\text { an object of } \\
\text { assessment }\end{array}$ & $\begin{array}{l}\text { An IS success/failure exists and is determined by } \\
\text { IS properties irrespective of the assessor. } \\
\text { As an object of assessment IS is assumed } \\
\text { passive and neutral. } \\
\text { Research has found that IS success/failure is } \\
\text { objectively represented using various measures: } \\
\text { - Information quality, system quality and service } \\
\text { quality } \\
\text { - Satisfaction with IS and realization of } \\
\text { expectations } \\
\text { - IS performance and functionality according to } \\
\text { predefined system objectives and specifications }\end{array}$ & $\begin{array}{l}\text { IS success or failure do not exist out there but are } \\
\text { created and negotiated through narratives, interpre- } \\
\text { tation, organizational discourses and political pro- } \\
\text { cesses as part of socio-technical and political } \\
\text { contexts. } \\
\text { Various research approaches have highlighted } \\
\text { - How IS success or failure emerges as the dominant } \\
\text { narrative, socially shaped and constructed by } \\
\text { powerful social groups } \\
\text { How success or failure is attributed to an IS imple- } \\
\text { mented and used by different social groups or } \\
\text { stakeholders, often involving organizational change } \\
\text { and innovation, political struggles and negotiations, } \\
\text { and legitimation of a new organizational reality }\end{array}$ \\
\hline
\end{tabular}

factors, including senior management commitment and support, active user participation, and other factors, have been causally related to IS project success (e.g., Biehl 2007; Currie 1997; Ewusi-Mensah and Przasnyski 1994; Fincham 2002; Lee and Xia 2005; Wang et al. 2008). Similarly, a range of factors has been found that are related to IS success (DeLone and McLean 1992, 2003; Dibbern et al. 2004; Doherty et al. 2011; Flowers 1996; Rai et al. 2002; Urbach et al. 2008;
Wang 2008) as indicated in Table 1. The contribution of objective/rational research is considered significant as the identification of factors and properties that are critical to achieving project and system success enables managers and IS professionals to focus their attention on managing and controlling a limited number of factors in notoriously complex IS projects (Remus and Wiener 2010). 
The representational nature of the objective/rational framing of IS projects and IS success has, however, a limited research agenda and contribution. Assessment criteria and representations of success imply that IS projects and implemented systems are static, abstracting their dynamic nature and social contexts. For instance, the factors determining IS success do not take into consideration that benefit realization takes time and that assessments of a system at different points in time would inevitably produce different outcomes (Doherty et al. 2011). Furthermore, the lists of factors do not take into account the variability of organizational, social, and political contexts in which factors may variously affect an IS project and system success (He and King 2008).

The subjective/political perspective, on the other hand, does not assume that success or failure of IS projects exist out there but rather proposes that they emerge and become perceived as such by specific organizational, socio-cultural, and political processes (Table 1) (see Bartis and Mitev 2008; Fincham 2002; Howcroft et al. 2004; Jones and Hughes 2001; Klecun and Cornford 2005; MacKenzie and Wajcman 1985; Mitev 2000; Myers 1994; Smithson and Tsiavos 2004). For instance, an early process model proposed by Sauer (1993) assumed no objective account of failure and focused on key stakeholders such as the project organization responsible for the development and maintenance of the information system and the project supporter/promoter who provides resources for the IS project. Both the success and failure of an IS project are seen as socially and politically motivated and created, often by a coalition of stakeholders.

A distinctly interpretive and narrative approach to IS success was proposed by Fincham (2002), who also rejected the assumption that success or failure exist as definite states, seeing them as narratives that emerge through sensemaking, interpretation, and attribution of meaning by various individuals, social groups, or stakeholders. This perspective emphasizes the subjective, interpretive, and political nature of assessments. By examining two case studies of IS projects, Fincham demonstrated how narratives change throughout the course of projects, including both success and failure at different times in each project. In another example, Bartis and Mitev (2008) demonstrated how the dominant narrative of a more powerful social group prevailed and disguised an IS failure as a success. By drawing attention to different perceptions and interpretations of the information system by different (relevant) social groups, they revealed how the IS success was socially and politically constructed.

Employing a range of theoretical foundations research within the subjective/political perspective provided important contributions to the understanding of various organizational and political processes of IS assessments and the attribution of success or failure. However, the framings of IS success within this perspective have been limited due to the representational nature of the assessments. Information systems and IS projects, as objects of assessment, are represented by subjective perceptions, interpretations, narratives, social constructions, or discourses by different social groups or stakeholders. Each group chooses the assessment criteria and interprets them to suit their interests, worldviews and objectives. Such representations of IS success downplay the role of information systems and IS projects and take them as passive objects of assessment processes.

While the two prominent perspectives on IS success - the objective/rational and the subjective/political — differ significantly, they both imply that assessments of information systems and IS projects are particular representations of reality. In both perspectives, the assessment of informatoin systems and IS projects is an "act of representation... [through which] the world is reduced to a more manageable, portable form" (Smithson and Tsiavos 2004, p. 213). Importantly, these representations of information system and IS project success are considered distinct and ontologically separate from what is being assessed, that is, information systems and IS projects. This is rooted in the Cartesian worldview that is deeply embedded within Western culture (Barad 2003). ${ }^{2}$ The key issue with such representationalist assumptions is that the practices and performances of representing and their productive effects are disregarded (Rouse 1996). By dealing with assessments of information systems as ontologically separate from information systemsthe objects that are being assessed - the messiness, indeterminacy, and arbitrariness of the assessment processes and their performative effects are disregarded or hidden. This has profound implications for reporting IS success and failure in industry surveys and the production of a particular picture of IS failure rates.

\section{Toward a Performative Framing of IS Success}

The performative perspective on IS success is proposed here as a nonrepresentational mode of theorizing. The performa-

\footnotetext{
${ }^{2}$ Representationalism is defined in Encyclopaedia Britannica as "philosophical theory of knowledge based on the assertion that the mind perceives only mental images (representations) of material objects outside the mind, not the objects themselves. The validity of human knowledge is thus called into question because of the need to show that such images accurately correspond to the external objects" (http://www.britannica.com/EBchecked/ topic/ 498476/representationism). Rouse (1996), and Barad (2003, 2007), among others, examine the constraints of representationalist assumptions in theorizing the nature of scientific practices.
} 
tive perspective changes the focus from questions of accurate measurements or subjective/political assessments of IS success to questions of sociomaterial practices and the ways in which they produce realities and perform both IS and their success or failure. It is grounded in a sociomaterial worldview that has been articulated by scholars in science studies (Barad 2003, 2007), actor-network theory (ANT) and science and technology studies (STS) (Latour 2005; Law 1988, 1992, 2004, 2008a, 2008b; Mol 1999, 2000, 2002), and more recently proposed in organizational studies and Information Systems (Orlikowski 2007, 2010; Orlikowski and Scott 2008; Suchman 2007). The sociomaterial worldview in both the natural and social sciences questions the taken-for-granted nature of entities, that is, essentialist assumptions that humans and nonhumans, the social and the technological, have a set of essential properties that make them what they are and establish a priori the boundary between them. Instead, what humans and nonhumans are is seen as temporally constituted by discursive-material practices (Barad 2003, 2007; Law 2004). The performative perspective thus shifts the focus from uncovering the essences of things to the processes of their becoming: how they come to be seen as particular things and defined by certain properties and boundaries.

To appreciate the meaning of this particular non-essentialist view, it is important to understand that the sociomaterial worldview is underpinned by a relational ontology, which means that humans, technologies, and other nonhumans do not preexist as separate entities with given properties and boundaries but are enacted and emerge through relations in practice. They are relational effects. As Law explains, relational ontology

treats entities and materialities as enacted and relational effects. Its relationality means that major ontological categories (for instance, "technology" and "society," "human" and "non-human") are treated as effects or outcomes, rather than as explanatory resources (2004, p. 157).

The performative perspective is thus concerned with relations among actors - anything that acts or is acted upon, including those we have a habit of calling the human, social, and cultural, as well as the nonhuman, material, and technologicalwithout presuming their essential nature or properties. Instead, by focusing on relations, the performative perspective highlights their precarious nature: actors are constituted through relations as relational effects. This further implies that agency is not limited to humans. As Orlikowski reminded us,

Latour (1987, 1992, 2005) has long argued that agency is not an essence that inheres in humans, but a capacity realized through the associations of actors (whether human or nonhuman) and thus relational, emergent, and shifting (2007, pp. 1437-1438).

These dynamic and open-ended associations of heterogeneous actors - also called actor-networks or sociomaterial assemblages by ANT scholars ${ }^{3}$ (Latour 2005; Law 2004) - are thus seen as a primary focus of empirical studies ${ }^{4}$ seeking to investigate the emergence of agency and the performative production of actors and their boundaries as relational effects.

Actor-networks are dynamic configurations of actors engaged in and performed by particular sociomaterial practices that produce differences that matter, both the semantic (meanings) and the ontic (what exists) (Barad 2007; Law 2004). To understand the dynamics of associations in actor-networks and how differences are made and actors become performed, Barad $(2003,2007)$ proposed the notion of intra-action. In contrast to interaction, which assumes a form of interchange among independently existing actors (entities), the notion of intra-action denotes emergence and reconfiguration of actornetworks within which properties and boundaries of actors are continually reconstituted. Assuming the relational ontology, individual actors are not taken as given and preexisting before entering into relations; rather, they "emerge through and as part of entangled intra-relating" (Barad 2007, p. ix) and exist only in relations. "Outside of particular agential intra-action, 'words' and 'things' are indeterminate" (Barad 2007, p. 150). This is an important assumption that allows us to observe relations without initially ascribing actors any essential nature or properties. In other words, we are free to observe anything that acts or is acted upon, that is, actors, and their dynamic intra-acting within emerging actor-networks and discover how properties of actors and their mutual boundaries are enacted in relations, and thus become determinate. This implies what Barad called agential cuts: ${ }^{5}$

\footnotetext{
${ }^{3}$ Latour (2005), Law (2004), and Suchman (2007) use the terms sociomaterial assemblage and actor-network as synonyms; for simplicity, we will use the latter.

${ }^{4}$ Law (2008a) argues that the empirical and the theoretical in ANT and science and technology studies (STS) cannot be separated and that they are developed together: "Theory and data are created together [primarily through case studies and are a] major mode of self-expression, discovery and exegesis" (p. 629).

${ }^{5}$ Barad calls her particular ontological and epistemological framework agential realism. Agential realism is concerned with understanding entanglements between and developing a performative account of the human and the nonhuman, the social and the technological, the discursive and the material and how they intra-act and coproduce each other in practice. Agential realism, Barad emphasizes, "is not about representations of an independent reality but about the real consequences, interventions, creative possibilities, and responsibilities of intra-acting within and as part of the world" $(2007$, p. 37). It is
} 
It is through specific intra-actions that the boundaries and properties of the "components" of phenomena become determinate and that particular embodied concepts become meaningful. A specific intra-action...enacts an agential cut...effecting a separation between "subject" and "object." That is, the agential cut enacts a local resolution within the phenomenon of the inherent ontological indeterminancy (2003, p. 815).

As illustrated by several ANT studies, actors' properties and boundaries are typically in flux and become temporarily stabilized through specific intra-acting (in Barad's terminology) and thus come to be seen as specific objects and subjects, given and real (Callon 1986; Law and Callon 1997; Mol 2000; Orlikowski and Scott 2008). Instead of taking these temporally stabilized objects and subjects as given and real, the performative perspective focuses our attention on intra-acting in actor-networks and on particular sociomaterial practices of agential cuts that perform these specific objects and subjects with particular properties and boundaries.

Building on the above assumptions, the performative perspective on IS assessment is concerned with the emergence and reconfiguration of IS project actor-networks and the ways in which particular assessments are intra-actively produced and stabilized. Information systems are developed, take their form, and acquire their attributes as a result of ongoing intraactions and agential cuts within project actor-networks. The performative framing draws attention to the enactment of an information system in sociomaterial practices emerging through specific intra-actions among actors that come to be seen as developers, technologies, methodologies, tools, users, managers, contracts, business processes, plans, documents, etc. ${ }^{6}$ Information systems emerge, are produced, implemented and used through relations among the actors in project actornetworks. Consequently, information systems as well as IS assessments have no independent existence outside of these relations and actor-networks.

This further suggests that, to understand IS assessments, we have to explore IS enactments located and situated in practice and focus on the dynamics of relations among numerous actors and the emergence and reconfiguration of actornetworks leading to agential cuts by which the realities of suc-

about making and remaking realities and how they matter.

${ }^{6}$ In ANT terminology, these are actors or actants enrolled and continually performed in heterogeneous actor-networks (Callon 1986, 1991; Latour 2005). In this paper, we use the generic term actor to denote anything that acts or is acted upon. cess or failure are performed. This brings us to an important proposition that IS enactments in different sociomaterial practices can in principle produce different realities, including different IS assessments. The point here is not that there are various views of a single true reality of an IS success but that there are multiple realities of IS assessment produced by practices in different actor-networks. As Law explained, "the world is not simply epistemologically complex. It is ontologically multiple too" (2008a, pp. 636-637).

To explore how different IS enactments can produce different realities including different assessments, we draw from the concept of ontological politics: ${ }^{7}$

If realities are enacted, then reality is not in principle fixed or singular, and truth is no longer the only ground for accepting or rejecting a representation. The implication is that there are various possible reasons, including the political, for enacting one kind of reality rather than another, and that these grounds can in some measure be debated. This is ontological politics (Law 2004, p. 162).

In the world of IS practices, we are talking about situated enactments and various reasons why an IS project and an information system enacted in a particular location, that is, a sociomaterial practice in an actor-network, create one kind of reality rather than another. The question of IS assessment and the production of multiple realities of IS success or failure can thus be debated in terms of doing different ontological politics.

The performative perspective provides conceptual apparatus for an alternative framing of IS success that is sensitive to the emergence of project actor-networks, ontological politics, and situated sociomaterial practices of IS projects within which and by which information systems are enacted and success or failure performed. It also provides concepts to explore how particular local configurations and agential cuts in different actor-networks temporally stabilize and thus enact specific and potentially competing IS realities, including a success or failure. Generally, the performative perspective enables us to pose and explore an interesting research question: How do

${ }^{7}$ Mol was first to define ontological politics:

Ontological politics is a composite term. It talks of ontologywhich in standard philosophical parlance defines what belongs to the real, the conditions of possibility we live with. If the term "ontology" is defined with that of politics, then this suggests that the conditions of possibility are not given. That reality does not precede the mundane practices in which we interact with it, but is rather shaped within these practices (1999, pp. 74-75). 
different and potentially competing assessments of information systems and IS projects arise from different sociomaterial practices? We explore this question and ground the performative perspective on IS success by investigating the case study. We now present the research methodology, introducing first our research site and then the description of the study.

\section{Research Methodology}

\section{Research Site}

We conducted the case study in an Australian insurance company that deals primarily in general insurance, life risk, and investments. The company, called here Olympia, is a medium size firm with $1200+$ employees, a part of a large multinational insurance group operating in over 170 countries. In 2001, Olympia undertook to become the first insurance provider in Australia of web-based e-business services to their brokers. Without much experience, Olympia embarked on the development of a web-based information system, called Olympia-online, to enable selling their business insurance products online. Four years in the making, in 2005, Olympiaonline emerged as a sophisticated information system, eagerly adopted and highly praised by the broker community. Olympia-online's success in the broker community created an evident competitive advantage for the company: a sharp increase in their earnings and profit margins. However, Olympia's Steering Committee, including two top business managers, was dissatisfied with some of Olympia-online's functional deficiencies, its rising costs, and its unsatisfactory cost-effectiveness. Two years after the second successful implementation and despite the huge success in the market (more brokers selling Olympia insurance products and generating business for Olympia), the Committee declared Olympia-online a failure and withdrew its support for funding its future development.

Olympia-online was an industry-first e-commerce system in the Australian insurance market that transacted the company's insurance products directly to brokers over the web. The final Olympia-online system was highly innovative in the way it presented the company's insurance products and enabled online engagement and interaction with brokers as they sold these products to clients. However, the withdrawal of support by the Steering Committee for further Olympia-online development created a worrying situation for the company. Olympia-online was vital to the company since all of its business was mediated through brokers and, unlike other insurance companies, it had no direct contact with individual clients in the general insurance domain. As its only channel for transacting business with brokers, Olympia-online was seen throughout the company as being of strategic importance. That Olympia-online was considered simultaneously a success and a failure, with both assessments supported by evidence, was indeed puzzling. The Olympia-online project thus presented an exemplary case ${ }^{8}$ through which to examine our research question.

\section{The ANT Study}

Contact with Olympia was established during the second half of 2004 when one of the authors, a part-time research student at the time, worked as a member of the Olympia-online implementation and testing team. Intrigued by the Olympiaonline project, this author put forward a proposal to conduct a research study on the development and implementation of Olympia-online. Before the end of her contract with Olympia in December 2004, she received permission (including university ethics committee approval) to conduct research in the company. She then spent six months (February-August 2005) in the company, this time as a full-time researcher conducting an ANT field study. The two other authors were engaged as outside observers (Walsham 1995) and supervisors. Visits to the company continued in the second half of 2005 and during 2006.

The ANT study started with the researcher (author) in the field and two other authors involved in the study design, data analysis and interpretation. The researcher in the field was engaged in observations, discussions, and interviewing while continually presenting and discussing the experiences and the data collected with the two other authors. In this way, we interpreted the data and questioned the findings during the fieldwork, which then directed further data collection. Our ANT study continued beyond the fieldwork — piecing together a trajectory of the Olympia-online project actor-networksuntil November 2006. Hence, the ANT study effectively took place during the period February 2005-November 2006 with the three authors working closely and with a varying level of involvement in the field. ${ }^{9}$

\footnotetext{
${ }^{8}$ We borrow here from Kuhn (1962) and in particular Law (2008a) who argued that we learn from "exemplary historical moments and episodes" (p. 629) and that the "abstraction is only possible by working through the concrete" (p. 630). Empirical case studies are thus seen as important in STS "because they articulate and re-work theory" (p. 630).

${ }^{9}$ It is worth noting that the first 6 months of working on the Olympia-online testing and implementation, which preceded the ANT study, were highly useful for acquiring knowledge of the insurance industry, the Olympia company and its market situation, interaction with brokers, and, in particular, Olympia-online's architecture and application software, its implementation, and maintenance issues. Knowing the people and the Olympia-online project was very helpful for the research student to get access and collect data.
} 
A word about our choice of ANT is in order here. We chose ANT as a distinctly sociomaterial methodology (Alcapidani and Hassard 2010; Law 2004, 2008b) that provides analytical tools for a sociomaterial analysis. ANT fosters, as Law (2008b) explained, "a sensibility to the messy practices of relationality and materiality of the world" (p. 142). To adopt ANT, however, does not mean to apply a singular methodology or a set of prescriptions to conduct an empirical study (Latour 2005; Law 2008a, 2008b; Ramiller and Wagner 2009). ANT, together with its methodological principles and tools, needs to be translated into a particular research practice, which in turn changes ANT as a methodology as well as changing us, the researchers - an interesting topic but beyond the scope of this paper. To describe how we adopted ANT to conduct a sociomaterial analysis of the Olympia-online case, we present briefly (1) the mode of investigation, (2) the means of inquiry, and (3) the practices of reassembling the story and producing knowledge claims.

The mode of investigation involved tracking and tracing the unfolding relations since the beginning of the Olympia-online project to discover how actors seen as humans, technologies, documents, and others created space, time, and a network of relations to construct and carry forward the Olympia-online project. We started with relations among the actors involved in the testing and implementation of Olympia-online and from there expanded to relations with other actors and locations. This was a messy process in which we discovered relations that had created particular documents (the business case, scope document, contracts, licence, test plans, minutes), ${ }^{10}$ technologies (mainframe computer, rule-based software engine, application software) and specific roles and identities of project managers, architects, business analysts, application developers, testing team, brokers, and others (see the Appendix). We also learned from them how they created actornetworks. For instance, we traced the initial relations among managers and developers around a business case document, which grew into an Olympia-online project actor-network that created a space where the project objectives, scope, and time lines were negotiated and resources allocated.

In this process, we were assisted by the Information Services Department, which provided an organizational chart with the official roles of human actors and reporting relationships presented in Figure 1. These actors are also listed in Appendix Table A1 together with their pseudonyms, roles, and tasks. ${ }^{11}$ This helped us to track down the actors in charge of

\footnotetext{
${ }^{10}$ Most documents were confidential, could be read only at the company premises, and could not be cited without special permission.

${ }^{11}$ We note here that the "pre-given" roles (resulting from earlier intra-actions) were important for our understanding of their actions and responsibilities but they did change together with their identities as the study progressed. At any
}

certain actions who could "give us a story" (Ramiller and Wagner 2009, p. 48) and describe events and actions that we could not experience ourselves. The researcher in the field had at least some informal discussions with all the actors on the scene during the period February-August 2005 (22 actors from the chart on Figure 1 and two brokers involved in testing) and also formally interviewed 13 of them. ${ }^{12}$ Furthermore, to understand how technologies and documents were created as actors in the actor-network (listed in Appendix Tables $\mathrm{A} 2$ and $\mathrm{A} 3)^{13}$ and how they acted and were acted upon, we investigated traces that they had left and the effects performed (Bruni 2005). For instance, we followed the mobilization of a rule-based software engine into the IS development actor-network and observed how it initially became a key platform for building an innovative system. It later emerged into an actor that required significant additional work to be useful, slowing down the development. We also traced how this software acted as a delegate for the company that was contracted to assist in the development.

Like any study of practice, our study grew bigger, more complex, and difficult to manage as we delved into various paths that the tracing of relations took us. Therefore, we had to limit our study to the assembling and reconfiguration of the Olympia-online project actor-network and its ultimate decomposition into two emerging actor-networks within which the project and its outcome (Olympia-online) were performed and assessed. ${ }^{14}$

An issue with our study was that we arrived at the scene after the project was well under way. Tracing the relations was, therefore, not limited to the present and often moved to the past. In interviews and informal discussions, the human actors habitually referred to what had happened before, how other actors behaved, what decisions were made and how

point in time, an actor acquired a particular identity and acted depending on relations (past and present) with other actors.

${ }^{12}$ Interviews were taped and transcribed and notes from informal discussions typed.

${ }^{13}$ It is important to note that Figure 1 and the Appendix reflect a typical distinction between humans and nonhumans, including some taken-forgranted properties made in practice. This, however, should be understood as resulting from the prior intra-actions among the various actors and agential cuts that produced people in their particular roles, documents with certain meanings, and technologies with specific characteristics. While documenting these, we do not see them outside relations with other actors. As we followed some actors we saw how their relations changed and how their properties and boundaries transformed.

\footnotetext{
${ }^{14}$ We were able to focus our study on the Olympia-online project as it was rather disconnected from other projects, such as the development of the interface with the e-commerce platform Horizon carried out by a third party.
} 


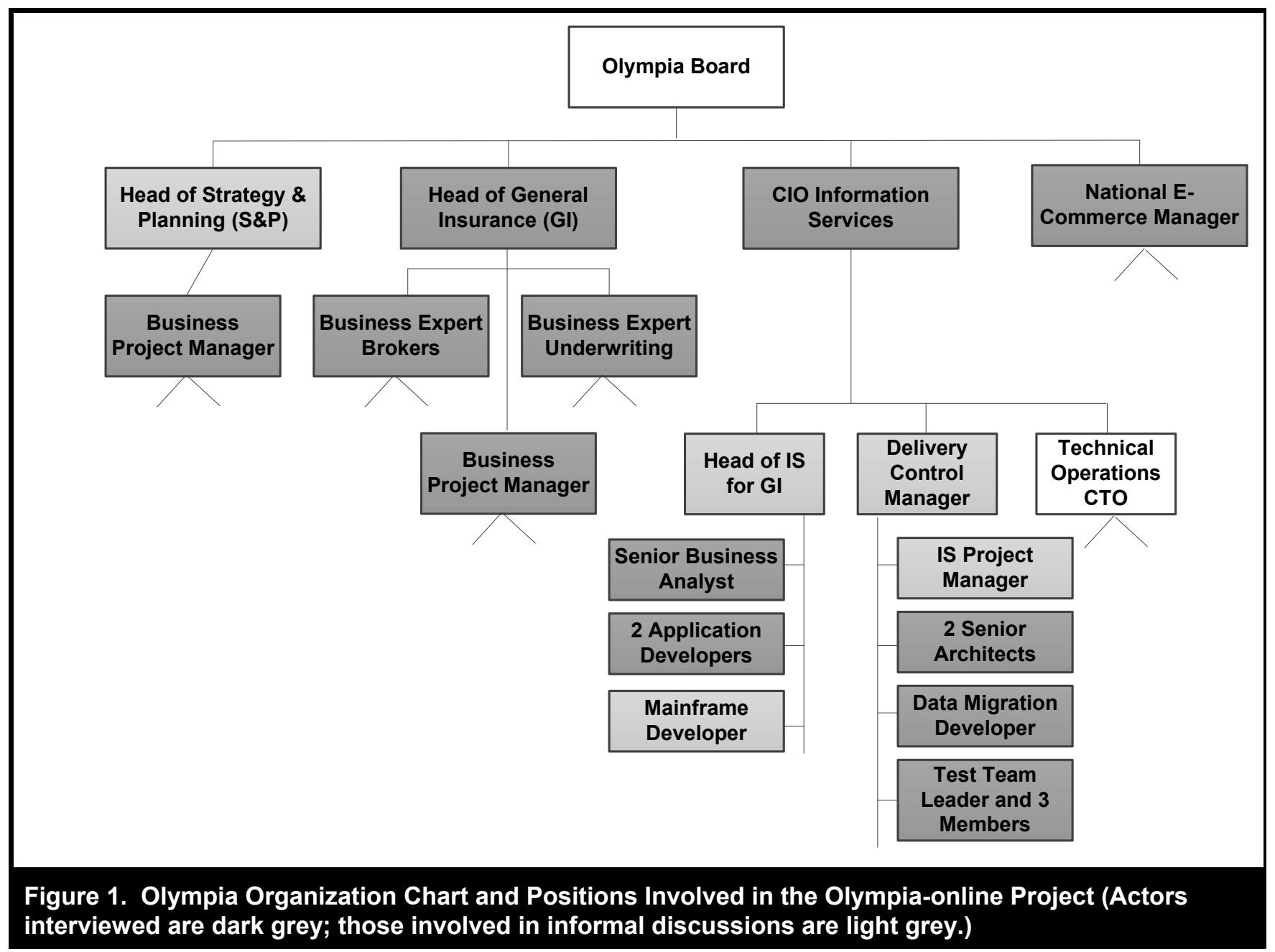

these preceding events conditioned or influenced the current situation. In ANT parlance, the actors were not able to explain present relations and actor-networks without tracing their emergence historically. ${ }^{15}$ In this respect, we faced challenges as our ANT study tended to extend in many unexpected directions. However, we learned to re-scale and refocus our study in space and time as we progressed, confirming Ramiller and Wagner's observation that ANT enables an "adaptable view on the scope of what should, in the actual fieldwork, be followed up on, tracked and traced" (2009, p. 45).

\footnotetext{
${ }^{15}$ Such historical tracing of actors' relations and their network building was also assisted by project documents (listed in Appendix Table A2). Our approach to historical tracing of actors and their relations was inspired by Law and Callon's (1997) examination of an aircraft project in the United Kingdom.
}

The means of our inquiry-observations, interviews, informal discussions, reading of documents - had a lot in common with ethnography. The researcher was not located outside but was a part of the world being studied. However, our approach to human actors in the field differed from an ethnography: we did not engage with them as "informants" but rather as producers of their own realities and theories. We learned from them how they constructed their associations and "what the collective existence has become in their hands, which methods they have elaborated to make it fit together, which accounts could best define the new associations" that they established (Latour 2005, p. 12). It is important to clarify that actors' accounts can be seen as both subjective and objective, as can anything else they did or performed. Their accounts disclosed their engagements with other actors (both human and nonhuman) and the effects of these engagements in a particular way. At the same time, actors' accounts testified to reality-making practices of which they were a part and through which they themselves and the world around them 
continually changed. In actors' accounts there arose, therefore, a specific "subjectivity" of human beings and a specific "objectivity" of a reality-making practice (Verbeek 2005).

Finally, we provide a few words on our practices of reassembling the story and producing knowledge. During the fieldwork, we continuously interpreted and questioned the material at hand in an attempt to reconstruct the enfolding relations, actor-networks, and their effects. This included discussions about and the construction of alternative explanations. Importantly, such processes were not separate from the fieldwork as they continually fed back and impacted on the fieldwork. This indicated that our practices of knowing and reassembling the story were intertwined with our engagement with actors in the field (observing, interviewing, and discussing). Hence, achieving objectivity was not about producing "undistorted representations" of a preexisting reality at a distance; rather achieving objectivity was about constructing knowledge "accountable to the specific materializations [in the IS project] of which we [were] a part" (Barad 2007, p. 91).

This was the most difficult aspect of our study: being accountable to the enfolding sociomaterial practices since the start of the project. This was difficult because (1) our engagement was limited to the actors available during our presence in the field, (2) tracing of relations was limited by actors' recollections and our access to relevant documents, and (3) the reconstruction and piecing together of fragmented stories and documented traces were inevitably a translation and thus simplification and betrayal. Furthermore, there was a tension between the tendency to produce detailed accounts of practice and the request to protect company interests. ${ }^{16}$ The story of Olympia-online that eventually emerged resulted from its testing, negotiation, and adaptation in the field but was also rewritten to be comprehensible to the reader.

To tell the story and keep track of the emergence of actornetworks, and to analyze their dynamics and trajectories, we presented actor-network maps at different points in time along the project time line inspired by Sarker et al. (2006). Despite inevitable simplifications, these maps were helpful for indicating and discussing the actors' enrollments and associations, that is, relations in actor-networks, and also for keeping track and discussing emerging reconfigurations. The maps have a meaning only as part of an ANT story and should not be

\footnotetext{
${ }^{16}$ The agreement with the company was explicit in terms of the protection of information about the project. The description of the project, and especially technical details about the Olympia-online system, had to be approved for publication.
}

interpreted as literal networks. ${ }^{17}$ The actor-network maps are also a good reminder not to confuse the ANT method and the maps with the territory: the method and the maps helped us to deal with infinitely complex, uncertain, and unlimited territory.

Through the ANT study described here, we addressed our research question and exposed different enactments of the Olympia-online project in practice and the ways in which they produced different realities, including competing assessments of both the project and the system. But before embarking on our ANT analysis, we briefly present the story of the Olympia-online development.

\section{The Olympia-online Story}

According to the General Insurance (GI) managers, Olympia was not seen as a major competitor in the Australian general insurance market prior to the development of its Olympiaonline system. All e-business in the Australian insurance industry was conducted via BrokerLine, an outdated mainframe-based electronic platform, run by Telcom, an Australian telecommunications company. More so than for any of its competitors, this platform was vital to Olympia since all its business was electronically mediated through brokers, and Olympia had no direct contact with individual clients in the general insurance domain. Early in 2001, Telcom announced to the industry that they were shutting down BrokerLine, offering instead a new web-based ecommerce platform, Horizon. Unlike Olympia, most insurance companies transacted their business both directly with individual businesses and via the brokers. This is why the GI Business Division was particularly concerned that they might lose all of their business. But they also recognized the opportunities to use Horizon to innovate selling their insurance products and their relationships with brokers. Together with the Strategy and Planning Division, they went about putting a business case for the development of a new web-based information system, Olympia-online, to enable innovative transacting with brokers via Horizon. The Information Services Department was charged with developing Olympiaonline as described in the business case documentation. As it would be the only channel through which Olympia would interact with brokers in the future after the closure of BrokerLine, the development of Olympia-online was strategically important.

\footnotetext{
${ }^{17}$ Apart from presenting an abstract and simplified picture, graphical representations have a drawback of being static and not allowing presentation of dynamics and fluidity of networks. This point is discussed by Latour (2005, pp. 132-133).
} 
Olympia-online was a new type of IS in the insurance industry. The Information Services Department had neither the experience nor the necessary skills and resources to develop the system in-house. Olympia, therefore, commissioned several companies to develop prototypes using different technologies. Only one company, HighTech, demonstrated a viable prototype using Emperor, a proprietary rulebased engine of which they were the sole reseller in Australia. A fixed-price contract with HighTech, signed in July 2001, marked the beginning of Phase 1 of the Olympia-online development. Phase 1 was contracted for three months, until the end of September 2001, but actually ended in mid-2002; Figure 2 presents major events and the time line of the Olympia-online project.

\section{Phase 1: Olympia-online Development}

The HighTech team moved to the Olympia premises in July 2001 and together with the Olympia team from the Information Services Department started the development. Once development was under way, several problems emerged. The Olympia team realized that the HighTech developers had no knowledge of the insurance industry and had not grasped the breadth and depth of the Olympia-online development. In retrospect, the head architect, George, from Olympia who had been involved in commissioning the HighTech company, admitted that the HighTech team "didn't understand the problem at hand, and underestimated its complexity, costs, and the required time to develop the system."

The key design issue in developing Olympia-online was the use of the rule-based engine, Emperor. George recalled how the HighTech project manager convinced him before the contract was signed that Emperor was the appropriate software for modelling insurance products. The HighTech project manager, however, never fully disclosed Emperor's capabilities and limitations. Working together with the HighTech team, the Olympia team gradually realized that Emperor "was not the right engine for the [Olympia-online] purpose." When used to model insurance products and their complex business rules, Emperor exhibited severe limitations and rigidity. ${ }^{18}$ For instance, for a type of insurance policy (business or vehicle insurance), several important elements figured in the calculation of a premium: the amount and conditions of coverage (specifying inclusions, exclusions, and limitations), details about potential types of risk, and the assessments of risks.

\footnotetext{
${ }^{18}$ Emperor was never intended to model insurance products; it contained generic hierarchical structures with simple rules attached to the nodes and was previously used for specifications of manufacturing products and their structure.
}

The developers could not find an elegant way of programming the rules of individual insurance products and calculations of premiums in Emperor and thus had to add specific routines and other processes on the mainframe, outside of Emperor. The design of the Olympia-online application software became cumbersome and time consuming. During the interview, Alan, the HighTech systems analyst, confessed

[Emperor] isn't the most mature product, it's not an [insurance] industry standard product, and I'm not sure it's the best fit for what we're trying to do here. I know it's not the best fit for what we're trying to do here. It was oversold, if you want the honest truth. I know because I know the guys that were selling it.

There were also problems integrating the software components built on Emperor with those on the mainframe. George reflected on the difficulties involved:

[The HighTech project manager] probably had the most experience-I mean the rest of us had zero experience with Emperor. He probably had the most experience but not enough to make [efficient] critical decisions....Every time you would suggest "let's not do this in Emperor, let's do it outside [on the mainframe] and let's do it like this, there'd be four more reasons on, "no but, if you don't do it like this then this will break in Emperor," or something like that.... which we later found was not exactly correct....So, the point is we were highly dependent on them [the HighTech team. We should have taken the] decision to move a lot of this functionality, which logically should never have lived in Emperor, and which logic at that point said "don't do it."

Sunil, a HighTech architect, further explained how, as Phase 1 advanced, the relationship between the HighTech team and the Olympia team became more contentious, primarily due to design issues related to Emperor and the mainframe system. He also noted that the more the application software relied on Emperor "the more Olympia depended on the [HighTech] company."

The HighTech project manager and the Olympia head architect had trouble ensuring the delivery of the system on time and with the specified functionality. At the beginning of 2002, as Phase 1 Olympia-online was significantly delayed, the head of the General Insurance (GI) Business Division, Roger, publicly announced to the brokers that the new system would be available with full functionality by mid-2002. This upset the Information Services staff, as George noted: 


\begin{tabular}{|l} 
Major events and actions \\
\hline 1. Telcom announces the replacement of BrokerLine, its outdated mainframe \\
e-business platform, by a new web-based platform Horizon \\
2. Olympia GI top managers together with the Information Services \\
Department submit a business case for a new web-based system Olympia- \\
online for selling insurance products to clients via brokers
\end{tabular}

3. Contract signed with the HighTech company; the Olympia-online Phase 1 development starts with the HighTech team and the Olympia team (from the Information Services Department) working together

4. The Olympia team experiences significant difficulties with Emperor leading to contentious relations between the Olympia team and the HighTech team, requiring more resources and time for development

5. GI top managers strengthen their relations with the HighTech team while weakening relations with the Olympia team

6. $\mathrm{Gl}$ top management announces Olympia-online to the brokers

7. Development work intensified focusing on the functionality for the brokers and delaying the work on internal functionality

8. Olympia-online goes live successfully in July 2002; brokers are delighted with Olympia-online and the new ways of doing business with Olympia; wide adoption of Olympia-online increases income

9. Top managers - not aware of difficulties - purchase an Emperor licence (AUS\$1 $1 \mathrm{mil}$ ) for future development

10. The Olympia team proposes redevelopment as Olympia-online is unstable and difficult to maintain

11. The Phase 1 implementation stoped and the Olympia-online Phase 2 is initiated; A Steering Committee formed, introducing a strict budgetary control and discipline and timely delivery as key success criteria; the Phase 1 IS project manager is made redundant a new IS project manager and a business project manager appointed

12. The Olympia-online Phase 2 development continues; the Olympia team questions the use of Emperor for Phase 2 but realises abandoning it is unfeasible after the purchase of the licence

13. The Olympia-online Phase 2 development is intensified but problems with the complexity of the application software design (based on Emperor and the mainframe) continue; the Phase 2 development team faces difficulties in fulfilling information requirements and delivering the desired functionality by the deadline; a request for additional resources sent to the Steering Committee

14. Steering Committee does not approve additional resources insisting on the original budget and delivery deadline

15. Phase 2 development re-focuses on brokers' needs and leaves the development of internal functionality for later; business experts-liaising with brokers extensively engage in the testing and improvements ensuring full functionality and high quality for the brokers

16. Olympia-online Phase 2 goes live and becomes an 'instant success'; it is highly praised by brokers as a much superior system to Phase 1 or any of the competitors' systems; the project is seen as a success by the developers as it provided Olympia with a competitive advantage

17. Steering Committee disappointed with Olympia-online's lack of internal functionality and also with the Olympia-online project being again overtime and over-budget

18. Steering Committee decides that both the Olympia-online project and the Olympia-online system are failures; Steering committee does not approve Phase 3 development making the future development of Olympia-online uncertain

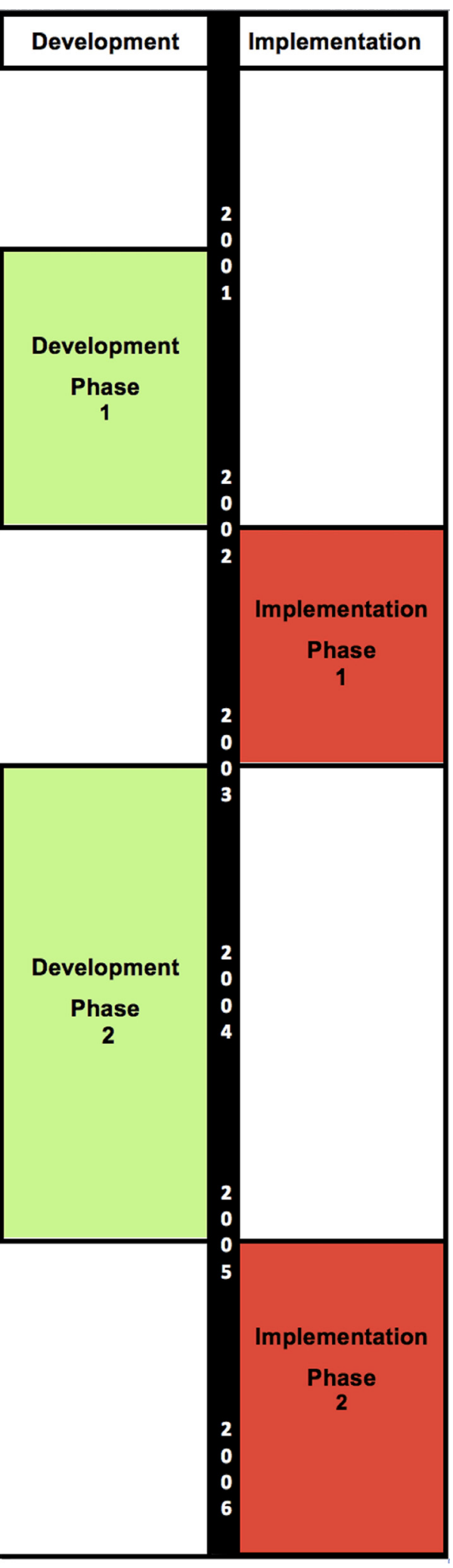

Figure 2. Olympia-online Development and Implementation Time Limit 
[We] had a huge blow out at that point between the developers, myself, the head of General Insurance, ... [they] shouldn't have gone out and promised that because there's no way in hell we can do it. We just had hundreds of defects outstanding, large parts of functionality not working....At the end of the day, they convinced us, everybody put in a huge amount of effort and we sort of got it working with one or two brokers, full functionality, ah, I think somewhere in July [2002].

When finally delivered to the brokers, despite a nine-month delay, Olympia-online attracted and delighted the brokers: it was the first web-based information system in the insurance industry. The web-based interface and interactive tailoring of insurance products transformed brokers' selling practices. Brokers were able to focus more on clients' needs and tailoring the products to meet those needs. During Phase 1 implementation (mid-2002 to mid-2003, see Figure 2), Olympia attracted new brokers and boosted GI business:

Olympia-online itself was a huge catalyst for [Olympia performance] in 2002, about packaged business because Olympia wasn't really seen as a serious package underwriter in the market. We're now seen as one of the leading package underwriters (Rene, senior GI Business manager).

Olympia-online's success was confirmed by the increase in the GI insurance revenue, which doubled in one year.

The GI business managers believed that Emperor was the key contributor to success. They were not aware of the problems experienced during the development nor did they realize Olympia-online's technical deficiencies and instability in operations. To ensure future development, GI business managers, on the advice of HighTech, made the decision to purchase AUS \$1 million worth of Emperor software licences. Information Services staff were not consulted and their objections to the decision were dismissed.

In the meantime, the Information Services staff were busy struggling to maintain an unstable system and responding to numerous defects. When the Olympia-online system became so unstable that its maintenance and use could no longer be sustained, they proposed Phase 2 of the Olympia-online development, which started in mid-2003 (see Figure 2).

\section{Phase 2 Olympia-online Development}

The document describing the Phase 2 development project explicitly stated two major goals: (1) to further develop specified functionality for both brokers and internal users, including GI managers, and (2) to deliver the new system on time and on budget. Consequently, the Phase 2 project was developed under a stringent project management regime. For this purpose, a Steering Committee was created consisting of stakeholders from the GI Business Division, the Strategy and Planning Division, and the Information Services Department. The Steering Committee was financially responsible for the project and thus primarily concerned with time frames and costs. Two new roles in Phase 2-the business project manager (Stuart) and the IS project manager (Sebastian) were directly responsible for the system's delivery on time and on budget. Phase 2, as the application developer Patrick commented, "focused disproportionately on short-term issues and cost considerations, at the expense of long-term quality and functionality." Chris, the business expert liaising with the brokers, had a similar observation: "[In Phase 2] there was always more of a consideration on the expenditure, the time frames that [Olympia-online] development was actually taking, rather than delivering the business needs." The tight budget control and the focus on deadlines increased tensions between the Steering Committee and the development team.

In Phase 2, Olympia-online development continued to experience problems with Emperor and with inadequate resourcing, as requests for additional resources were rejected by the Steering Committee. As a result, the Olympia team could not develop full functionality and decided to prioritize the desired functionality for the brokers. Furthermore, the two business experts (liaising with brokers and underwriting) pushed for high quality that, according to Chris, prolonged Olympia-online development "until a sufficient level of functionality and quality required by brokers had been delivered such that the new system would present as superior to both the existing [Phase 1] system and other web-based products developed by competitors in the meantime." This prolonged delivery caused tensions with the IS project manager who, according to Ron, the application developer, "was constantly pushing for fast delivery." The Phase 2 development, despite all of the issues, eventually delivered

a pretty good quality product to market, whilst it didn't have everything we needed, or we wanted, or that was originally scoped for the project, the standard of quality of the product that we delivered in the end was actually exceptional (Chris, business expert liaising with brokers)

This ensured that when Phase 2 Olympia-online eventually went live in mid-2005 it continued to delight the current brokers and attract new ones as well. This was acknowledged by the head of GI, Roger: 
The positive side of the [Olympia-online] is that it worked, it worked exceptionally well. Brokers do love it. The [Olympia-online] product is exceptionally well received in the market and we continue to get positive feedback that it's in front of our competitors.

However, he also emphasized the "negative side of Olympiaonline," which was too costly, over budget, and not flexible enough, and also "lacking internal reporting, which is very disappointing." This view prevailed in the Steering Committee, despite the evident market success. While they were initially enthusiastic about the Olympia-online development, the GI business managers did not engage with the Phase 2 development and were disappointed with the lack of internal functionality and the system's actual costs. When Phase $2 \mathrm{did}$ not deliver the requested internal functionality and when it became evident that the project was again over time and over budget, the Steering Committee decided that Phase 2 of Olympia-online was an "obvious failure."

The GI Business Division, ultimately responsible for funding future strategic initiatives, withdrew its support for further expansion and building of Olympia-online. The Steering Committee did not approve plans for a Phase 3. Other top managers disagreed. For instance, Olympia's national ecommerce manager, John, argued that

The problem we're going to have is that it's going to be too late if we try to react to something that happens in the next 6 to 12 months. So if we want to actually stay ahead [of the game], then we should be doing something now; but at the moment, we're actually told there's no budget for [the Olympiaonline development] to continue.

Not investing in the Olympia-online development and in further technical improvements and not continuing with further innovation, he added, might jeopardize Olympia's current market-leading position and expose the company to a high risk of failure in the marketplace. The future of Phase 3 development looked highly uncertain at the end of 2006 at the time of our last visit to the company..$^{19}$ In the following years, Olympia-online Phase 2 continued to be marketed to the brokers via the company website and, in 2010, an advanced version was announced with extended coverage of insurance products and new functionalities for the brokers.

\footnotetext{
${ }^{19}$ Subsequent attempts to get permission to continue the study and collect more data from Olympia were not successful.
}

\section{Analysis and Discussion: How Olympia-online Became Both a Success and a Failure}

In this section, we reinterpret the story of Olympia-online by conducting a sociomaterial analysis of the Olympia-online project from its inception using ANT methodology. We start by first focusing on the creation of an actor-network around the Olympia-online development, its dynamic reconfigurations, and its ultimate decomposition, enabling us to follow the trajectory of the Olympia-online project, the creation of different sociomaterial practices and the production of competing assessments of the Olympia-online project and the system.

\section{Emergence, Reconfiguration, and Decomposi- tion of the Olympia-online Actor-Network and the Enactment of Different Practices}

The Olympia-online Phase 1 project started with the business case that the GI Business Division and the Strategy and Planning Division, referred to here as the GI top managers, in collaboration with the Information Services Department, put forward in order to align Olympia's interests with the new ebusiness platform, Horizon. The actors- the GI top managers, the Information Services Department, Horizon and the business case - thus created an initial actor-network with the aim of developing the web-based Olympia-online system. These actors then together enrolled HighTech, the company that was to provide the rule-based engine, Emperor, and the necessary expertise for the development of the web-based system. Olympia's interests were thus inscribed in the Phase 1 business case document and the contract was signed with HighTech specifying the required functionality and the delivery deadline. The Olympia team from the Information Services Department together with the HighTech team were charged with the development of the application software using the mainframe resources and Emperor. These events and actions can be followed on the project time line in Figure $2^{20}$ (listed as numbers $1,2, \ldots$ ). The emerging actor-network of the Olympia-online Phase 1 project defined a space within which the project objectives, scope, resources, and time lines were negotiated. The network is illustrated graphically in Figure 3a using a simplified actor-network map inspired by Sarker et al. (2006).

\footnotetext{
${ }^{20}$ In our exploration of the emergence and reconfiguration of the Olympiaonline development actor-network we will remind the reader of key events and actions listed in the project time line in Figure 2 in order to follow the reconfiguration and ultimate decomposition of the network in Figure 3 as well as the description of the Olympia-online project trajectory in Figure 4.
} 


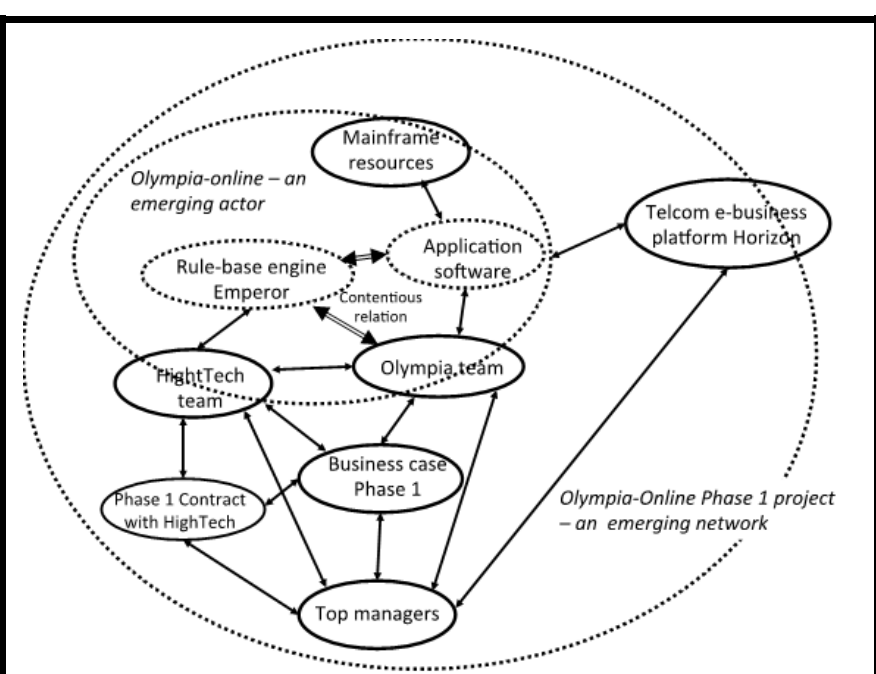

a. Olympia-online Phase 1 Development Network (mid2001 to mid-2002)

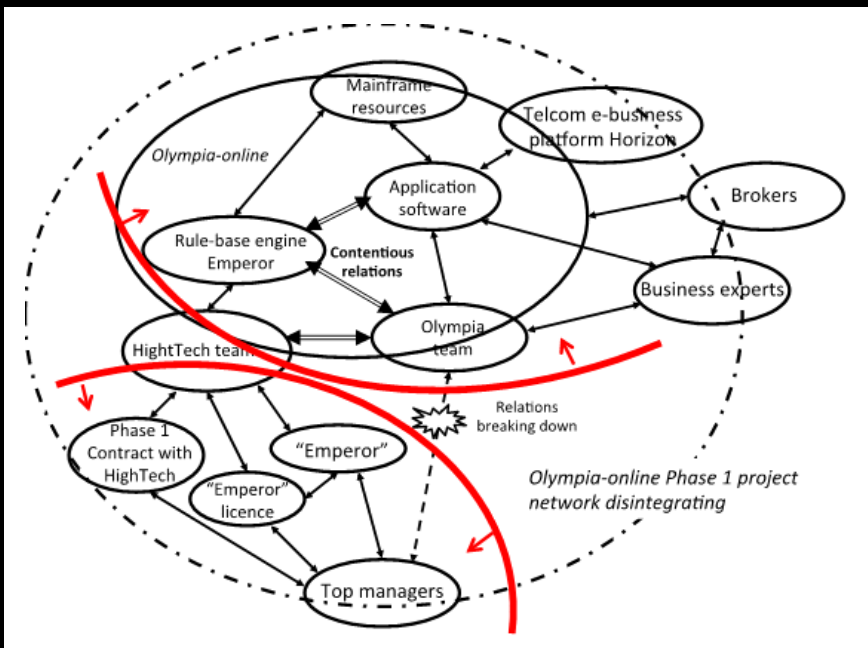

b. Disintegration of the Olympia-online Phase 1 Network (mid-2002 to mid-2003)

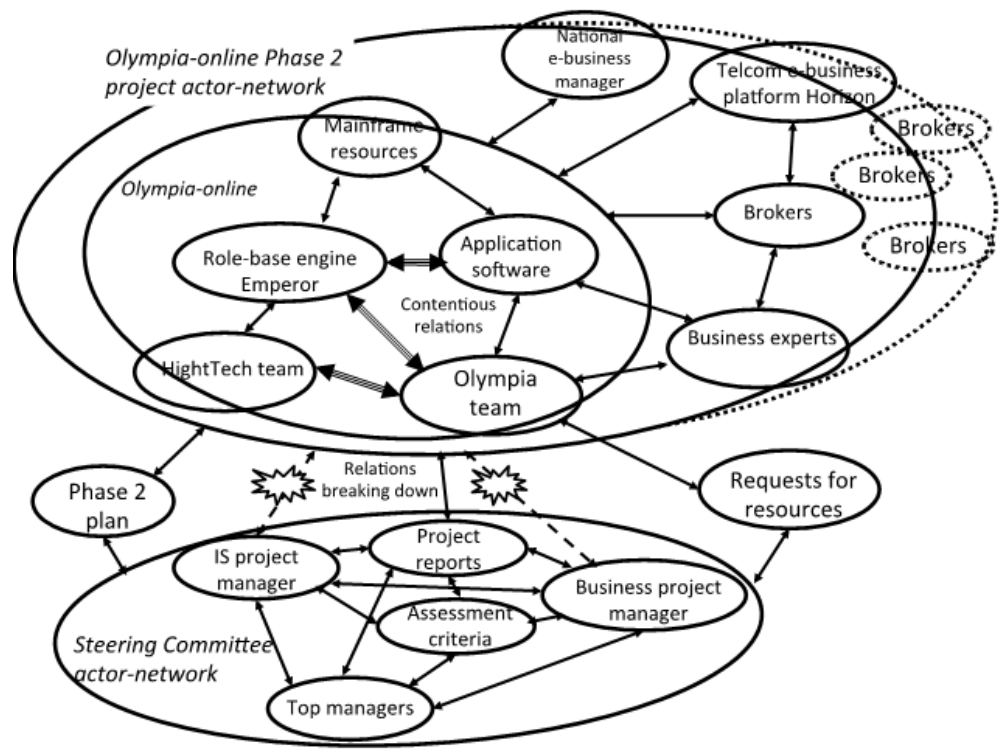

c. Olympia-online Phase 2 and Steering Committee Networks (mid-2003 to end of 2006)

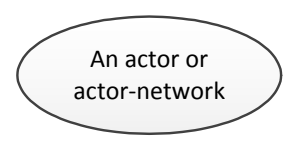

An emerging actor (actor-network)

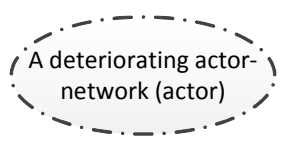

Figure 3. Emergence and Reconfiguration of the Olympia-online Development and Implementation Actor-Network 
As Phase 1 progressed, Olympia-online emerged as a key actor comprising an actor-network of mainframe resources, Emperor, the application software, the Olympia team, and the HighTech team (Figure 3a). The relations in this network revolved around the development of the application software for a selected class of GI products based on Emperor and the mainframe platform. The intra-actions within this network included the Olympia team and the HighTech team investigating and constructing the requirements together and then experimenting with different designs of the application software. Their relations were contentious as the Olympia team did not know much about Emperor, the HighTech team had no knowledge of the insurance industry, and there were no known types of information systems in industry from which to learn.

The intra-acting involved appropriation of Emperor to model complex insurance products so brokers could tailor these products to meet individual clients' requests, specify and assess risks, calculate a premium, and ultimately offer an insurance policy. Emperor was not appropriated as a general rule-based engine but as a specific rule-based engine to model various rules for risk specification and assessment, and for calculation of premiums. As the developers did not know how to model these rules in Emperor they experimented with alternative designs based on Emperor's rule structures with programmable extensions on the mainframe. The key issue in their appropriation of Emperor was an effective design of innovative modeling of insurance products. It was through this intra-acting that the agency of Emperor emerged, allowing some and resisting other design solutions. ${ }^{21}$ The agency of Emperor cannot be taken as given; it emerged through particular appropriations as part of alternative designs of the application software. As Phase 1 progressed, Emperor became an actor that did not support efficient design. The intra-action between Emperor and the other actors in the network enacted an agential cut, produced both materially and discursively in design practice, which effected its local separation and made Emperor an actor that betrayed the Olympia-online actor-network. Importantly, this transformation of Emperor's identity and role remained confined to this network.

Such intra-acting not only constructed Emperor as a particular rule-based engine inadequate for insurance products, it also (re)constructed the concept of the Olympia-online application software, what it is and does, and the identities and roles of the Olympia and the HighTech teams. For instance, the

\footnotetext{
${ }^{21}$ This does not mean that all potential ways for using Emperor to model insurance products were tried.
}

HighTech team, in the words of Marie the mainframe developer, were "concerned more with ensuring that [Emperor] was used rather than finding the best solutions for the application software" becoming "evidently driven by their company's interest." Their relations with the Olympia team, emerging as key developers concerned with Olympia's interests, became increasingly contentious. Such emergent intra-acting within the Olympia-online actor-network was thus ontologically reconstitutive: it recreated the actors and their relations.

As a result, Phase 1 development engaged more resources and took much longer than planned resulting in the delayed delivery (event no. 4 in Figure 2). During that time, the GI top managers focused on extending the contract with HighTech in order to ensure faster delivery of Olympiaonline. This move gradually strengthened their relations with the HighTech team while weakening the relations with the Olympia team (event no. 5 in Figure 2). The changing relations and transformations of actors, their roles, tasks, characteristics, and capacity to act, prevented stabilization of the Olympia-online Phase 1 project actor-network (Figure 3a). Starting with Olympia-online Phase 1 implementation mid2002, this network gradually decomposed, as illustrated in Figures $3 \mathrm{~b}$ and $3 \mathrm{c}$. The decomposition resulted from some seemingly unrelated reconfiguration processes originating within the Olympia-online Phase 1 project actor-network. We now describe selected episodes of these reconfiguration processes in order to trace the trajectory of the Olympia-online development and reveal their intended and unintended consequences.

After the GI top managers prematurely announced to the brokers that Olympia-online would go live in mid-2002 (event no. 6), the developers intensified the work and prioritized the design of the system's functionality for the brokers (event no. 7), thus postponing the delivery of internal functionality to some time in the future. The Olympia-online network extended its relations to the e-business platform Horizon and the business experts liaising with brokers and underwriting who eventually enrolled the brokers in testing the application software (Figure 3b). As a result, the brokers' interests were successfully translated, putting further pressure on improving the application software to meet their needs. The intra-action among the business experts, the development teams, Olympiaonline, and the brokers revolved around redesigning, finetuning, and testing the application software and the web interface for brokers. The critical focus of this intra-action was a sociomaterial entanglement of Olympia-online with the brokers' work practices in which a change in one triggered a change in the other in an iterative way. They were, to use Pickering's (1993) words, "mutually and emergently productive of one another" (p.567). The sociomaterial entanglement 
involved the testers from the Olympia team who payed particular attention to detail observing the ways in which brokers appropriated the Olympia-online system in their work practice: interacted with clients, specified insurance conditions, defined and assessed different risks, customized insurance products for them and ultimately executed transactions online with the Olympia company. Only through hands-on engagement with brokers while they used Olympiaonline was it possible for developers and testers to mutually grasp the depth of transformation and innovation of brokers' practices and then change and fine-tune the software and the interface of Olympia-online. As Chris expressed it, "they did an outstanding job... and actually contributed substantially to [Olympia-online] being a quality product" highly praised by the brokers.

When Olympia-online went live in July 2002 (event no. 8, Figure 2), it enrolled a large number of brokers who adopted it. The brokers' enactment of Olympia-online reconstructed their work practices and their professional identities, significantly transforming their interaction with clients and with Olympia. "It's not only that [Olympia-online] is interactive and that some fields are automatically populated...the whole process is transformed," explained a broker. "We have more time to focus on our core business,... build trust with our clients, provide advice on discounts, and suggest the best [insurance] product." When enacted in brokers' practices, Olympia-online recreated brokers' relations with clients through faster and more effective tailoring of insurance products as well as with Olympia through more efficient transacting of the business. The wide adoption of these new practices by the brokers created the market success ${ }^{22}$ of Phase 1 of Olympia-online and resulted in a significant increase in revenue for Olympia.

Reconfiguration of the Olympia-online Phase 1 network continued during the implementation period, from mid-2002 to mid-2003, leading to its gradual decomposition (see Figure $3 b)$. The GI top managers' commitment and increased support for the Olympia-online project was expressed by their readiness to invest in acquiring more expertise from HighTech. Through discussions and interviews with the GI top managers, we discovered a hidden actor, "Emperor".:23 from their experience, it was "Emperor" that made Olympiaonline successful. It is important to note that this enactment

\footnotetext{
${ }^{22}$ The analysis of the emerging actor-networks of brokers and clients that led to the success would have been interesting but we could not get permission to talk to brokers beyond the two involved in testing.

${ }^{23}$ To differentiate this "Emperor" from the Emperor in the Olympia-online network discussed above, we use quotation marks.
}

of "Emperor" was different from the one in the Olympiaonline network, but equally real for the managers; it was materially present when the HighTech team demonstrated the prototype model of an insurance product based on "Emperor" before the contract was signed. ${ }^{24}$ This enactment of "Emperor" as a powerful and crucial actor was further confirmed by Olympia-online's market success and was maintained through the relations among the GI top managers, the HighTech team and the "Emperor," but was not visible outside these relations. ${ }^{25}$ "Emperor" was further strengthened by the purchase of a $\$ 1$ million licence for unlimited future developments (event no. 9 in Figure 2). The rationale for the purchase was "Emperor's" key role in Olympia-online's market success, making its trace visible. The two actorsEmperor and "Emperor" - were enacted in different relations; they were different relational effects. These were not different perceptions or representations of a single technology but multiple forms of reality performed in these relations (Mol 2002). Both actors continued to play important roles after the decomposition of the Olympia-online Phase 1 project actornetwork.

As they initiated Phase 2, the GI top managers created a Steering Committee, a powerful new actor, charged with strict budgetary and deadline control (event no. 11 in Figure 2). This event, together with the disintegration of the Olympiaonline Phase 1 project network, already underway during the period of mid-2002 to mid-2003 (as shown on Figure 3b), led to the emergence of two actor-networks in Phase 2: the Steering Committee actor-network and the Olympia-online Phase 2 project actor-network (Figure 3c). During Phase 2 development and implementation, the latter network stabilized around Olympia-online development including intra-actions with Horizon, the brokers, and business experts. The Steering Committee network included two new actors - the IS project manager (Sebastian) and the business project manager (Stuart), who had no prior knowledge of the projectresponsible for monitoring and controlling the Olympia-online project. They imposed strict control and a reporting regime on the project. The GI top managers became more detached from the project network building instead tight relations within the Steering Committee network. The Steering Committee monitored the Phase 2 project via regular reports

\footnotetext{
${ }^{24}$ At the very beginning the GI top managers and IS managers were impressed with the highly efficient development of a prototype for a single insurance product based on "Emperor." They saw a small HighTech team doing it quickly, but did not know that a team of 20 designers worked in the background (hidden) to make this happen. ${ }^{25}$ As "Emperor" was not visible outside of the relations that produced it,
learning about it was only possible via the traces it left.
} 
presumed to accurately represent Olympia-online's progress, focusing on the selected aspects (costs and delivery) as specified by assessment criteria, a new actor in this network. The Steering Committee did not have to deal with the complex reality of the Phase 2 development but only with particular representations that replaced and simplified reality.

The decomposition of the Olympia-online Phase 1 project actor-network and the creation and emergence of the two networks in Phase 2 had considerable implications for the project, as we will now describe. At the start of Phase 2, the use of Emperor was debated again by the Olympia team. However, abandoning it was politically unfeasible:

While we did look at chucking [Emperor] it was politically not feasible...to go back to the [GI] business managers and say, "Guess what, guys? We're going to chuck it. A million dollars worth of software, because we don't think it's the right product" (George, the head architect).

Furthermore, George added, the more code and application software they developed based on Emperor, the less likely they were to abandon it. Emperor thus remained the rulebased engine in Phase 2 (event no. 12).

The application software in Phase 2 became even more complex due to new functionality requirements for brokers but also due to continued struggles with design solutions based on Emperor and the mainframe. The Olympia team requested more resources from the Steering Committee, arguing that the complexity of the system and the difficulties with Emperor necessitated more resources than initially planned (event no. 13). Within the Steering Committee network, this request was considered unjustified and was, therefore, rejected (event no. 14). The developers and the business experts then decided to focus on the requirements for the brokers, delaying again the development of internal functionality required by the GI managers (event no. 15). This was not known beyond the Olympia-online Phase 2 project actor-network and was first reported to the Steering Committee in May 2005. The project was not going to have internal functionality and was already over time and over budget. When they received the report, the Steering Committee soon decided to terminate Phase 2 development and start the implementation (mid-2005).

After Olympia-online Phase 2 went live (event no. 16), numerous brokers implemented it and thus effectively enrolled in the Phase 2 network (see Figure 3c). Having previous experiences with Phase 1, the brokers appropriated the Phase 2 system at a fast rate, expressing their appreciation for further improvements and increased efficiency in their work practices. Again, the enactment of Olympia-online Phase 2 in the brokers' work practices recreated brokers' relations with their clients and transacting with Olympia. These new emerging sociomaterial practices produced an agential cut: the Olympia-online system that delighted brokers and created market success; the Olympia-online project was thus considered a success despite the lack of internal functionality.

The sociomaterial practices in the Steering Committee actornetwork enacted a different Olympia-online project and produced a competing assessment. The intra-action among its actors created the assessment criteria as a prominent actor that played an important role in characterizing both the Olympiaonline Phase 2 project and the Olympia-online system, and in producing objective assessments (Figure 3c). The intra-action in this network performed an agential cut that made Olympiaonline Phase 2 project an over-time and over-budget project and Olympia-online a system that failed to provide required and ordinary internal functionality; thus both were assessed as evident failures (events nos. 17 and 18). While the Olympiaonline market success, which had been created in the Olympia-online Phase 2 network, was acknowledged, it was not part of the agential cut that was enacted in the Steering Committee network and produced the reality of the project and the system failure. The reality of failure had a detrimental consequence for the project: Phase 3 development was rejected.

\section{Ontological Politics and the Rise of the Agencies of Assessment}

The above analysis reveals the dynamic reconfigurations and decomposition of the Olympia-online actor-network and the production and stabilization of competing assessments of both the system and the project. The analysis provides empirical grounding for our examination of the key research question: How do different and potentially competing assessments of an information system and an IS project arise from different sociomaterial practices? We will explore potential answers by looking more closely into the workings of ontological politics in a particular trajectory of the Olympia-online network reconfigurations that led to the enactment of different sociomaterial practices. This discussion will allow us to reveal how the agencies of assessment arose and gradually built up in different and concurrent practices, thus producing competing assessments together with the objects of assessment.

The tracing of reconfigurations of the Olympia-online project actor-network, presented during different time periods in 


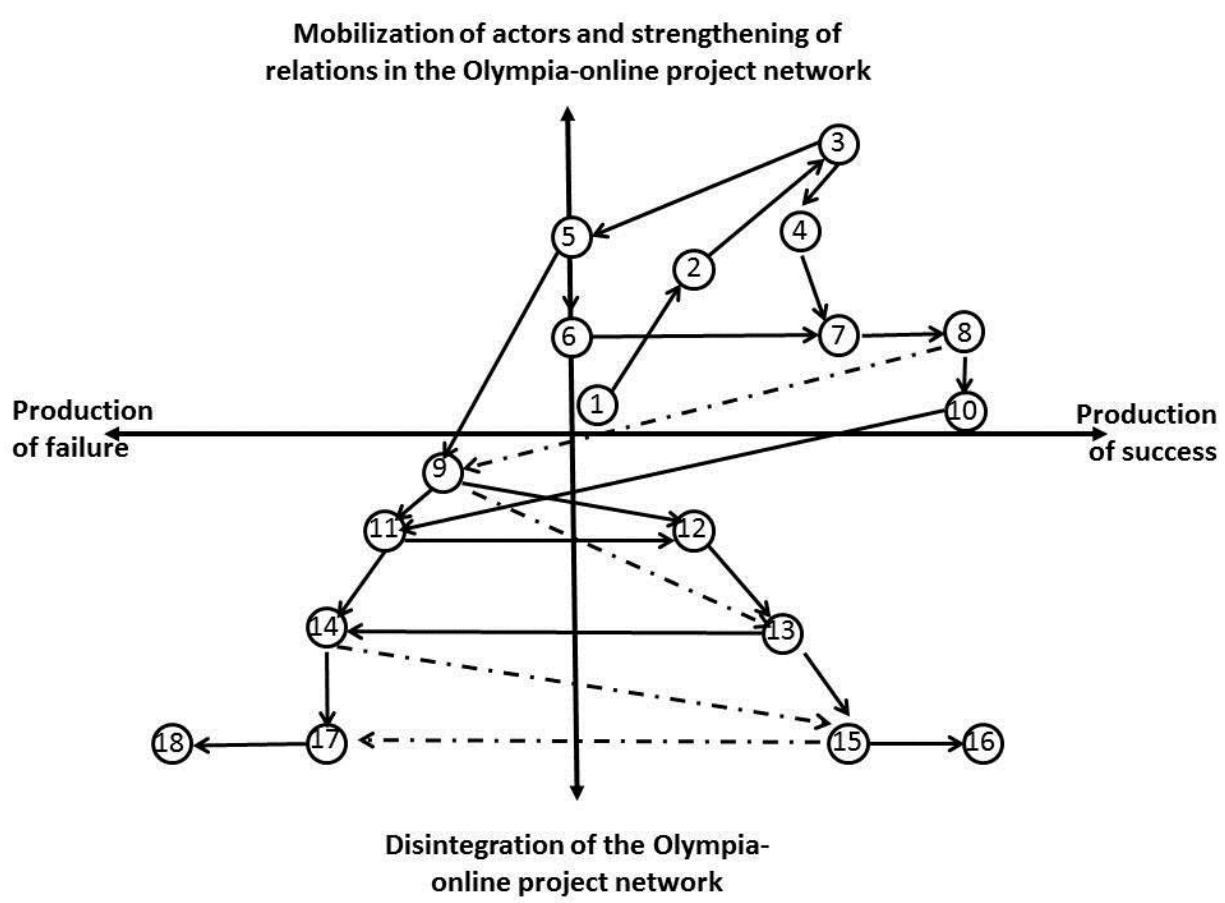

The location of each event from Figure 2 (events 1-18) depends on its contribution to the mobilization of actors and the strengthening or weakening of relations in the Olympia-online project network (vertical dimension) and to the production of success or failure (horizontal dimension). While the events in Figure 2 are temporally ordered, they are presented here as sequences of related events. When one event precedes another (depicted by an arrow), it either causes or triggers or leads to the other. When a precedence link is vertical and going upwards, it indicates increasing mobilization of actors and strengthening of relations in the Olympia-online project network (and vice versa). When the link is horizontal and going to the right, it contributes to the production of success (and vice versa). The dotted links suggest unintended and unanticipated influences.

Figure 4. The Trajectory of the Olympia-online Project Actor-Network (event numbers correspond to those in the project time line in Figure 2)

Figures $3 \mathrm{a}, 3 \mathrm{~b}$, and $3 \mathrm{c}$, can be seen as a trajectory that we now depict in a more compact form in a two-dimensional space (Figure 4). The trajectory of the Olympia-online project in Figure 4 succinctly describes the sequences of events that reconfigured the project actor-network and at some point triggered its decomposition: after event no. 9, two sequences of events (nos. 9-12-13-15-16 and nos. 9-11-14-17-18) followed, leading to the production of success and failure respectively. An interesting observation from the analysis of the trajectory and particular paths taken at certain points in time is that there is nothing inevitable in this trajectory. At any point in time, actions or decisions could have been different and the trajectory could have turned in another direction, opening different alternatives. There is, we might say, an inherent indeterminacy in the project network reconfigurations arising from different intra-actions. For example, after the Olympia team encountered problems with Emperor (event no. 4), a different course of actions could have been taken, such as to abandon Emperor, discontinue the contract with HighTech, and seek another rule-based engine; when the Steering Committee was created (event no. 11), it could have been mobilized into the Olympia-online Phase 2 project actornetwork; when Phase 2 development faced looming deadlines and a lack of resources, different actions could have been taken instead of postponing the development of internal functionality (event no. 15). At any point in time, the trajectory of the Olympia-online project could have taken a different direction, leading to different outcomes; this also means that some actions could have been reversible. ${ }^{26}$

\footnotetext{
${ }^{26}$ In some cases, though, reversibility may not be possible or can be costly. For instance the more the application software was developed based on Emperor, the more costly it became to abandon it and redevelop the software on another rule-based software engine. It would have been easier and less costly to do it in Phase 1 (event no. 4) than in Phase 2 (event no. 12).
} 
If the trajectory of the project and the production of assessments are not inherently determinate, the key question is, how do they become so? To explore this, we will discuss ontological politics in some key paths of the Olympia-online project's trajectory. Ontological politics implies that conditions of possibility in the creation and emergence of actornetworks and their sociomaterial practices are not given but enacted and reenacted (Law 2004; Mol 2000).

A critical moment in the project trajectory seems to have been the purchase of the Emperor licence (event no. 9) after which the trajectory of the Olympia-online project split into two parallel paths that produced different sociomaterial practices and competing assessments (see Figures $3 b, 3 c$, and Figure 4). The ontological politics working behind the decomposition of the Phase 1 network was evident in particular inclusions and exclusions. The build-up of relations among the GI top management and the HighTech team strengthened the position of "Emperor" leading to the purchase of the "Emperor" licence and further deterioration of relations with the Olympia team. The Phase 1 IS project manager was made redundant and the two new roles of an IS project manager and a business project manager were created in Phase 2; assessment criteria were also established (event no. 11). These inclusions, that is, particular ontological politics, reflected on the composition of the Steering Committee network (see Figure 3c). At the same time, this politics was exclusionary: they excluded the development team, the business experts, the Olympia-online network, other managers, and the brokers. Such ontological politics made a difference: it instigated a particular path (nos. 9-11-14-17-18) rather than some alternative paths in the project development trajectory; it also constituted the Steering Committee as the authority acting on the company's behalf.

The workings of ontological politics that produced the parallel path (nos. 9-12-13-15-16) involved different inclusions and exclusions in the Phase 2 project network. To continue the use of Emperor or to purchase another rule-based engine could be seen as a key political decision at the time. As we have seen, after the $\$ 1$ million investment in the Emperor licence, it became politically unfeasible for the Olympia team to abandon it. Furthermore, the amount of software built on Emperor during Phase 1 made it more difficult to "go back to a point where alternative possibilities exist[ed]" (Walsham and Sahay 1999, p. 42). While the continued use of Emperor was not inevitable, an alternative path was politically risky and too costly. Phase 2 development thus remained based on Emperor (event no. 12). As the difficulties with Emperor continued (event no. 13) and additional resources were not approved (event no. 14), the ontological politics in the Phase 2 network prioritized the development of Olympia-online functionality for the brokers, thus practically excluding the development of the required internal functionality (event no. 15). Furthermore, the inclusion of brokers in the intense intra-actions with the Olympia-online actor and the business experts, as we have seen, enacted the sociomaterial practice that produced the high quality Phase 2 system for the brokers (event no. 16).

By the end of 2006, the two paths, as shown in Figure 4, had produced different and competing assessments of the Olympia-online project and the system. To explain the production of the competing assessments, we propose a new concept: an agency of assessment as a specific kind of agency that arises through intra-actions and shows up in the resulting sociomaterial practice that enacts a particular assessment together with the object of assessment, as an agential cut. In the Steering Committee network, the emergence of a particular agency of assessment can be traced back to the ontological politics that excluded the Phase 2 project actornetwork and instead included the project reports from this network as true representations of the project. The ontological politics in this network also included the assessment criteria, an actor that produced a particular view of what a successful project and a successful system were, that is, a "project completed on time and within budget" and a "system delivered according to specifications" (as specified in the Steering Committee meeting minutes). Such views, as Smithson and Tsiavos (2004, pp. 214-215) remind us, are specific representations that translate and reduce the IS project and the system assessment into simple, fact-like, and objective measures. The intra-acting within the Steering Committee actor-network thus created a particular sociomaterial practice in which these representations constituted the Olympia-online project as one that was over time and over budget, and Olympia-online as a system that failed to deliver ordinary internal functionality. As this network temporally stabilized, the agency of assessment ultimately enacted both the particular objects of assessment, that is, the project and the system, as well as their assessments, as an agential cut. In other words, the agency of assessment that arose in this network (by the end of 2006) and became ingrained in its sociomaterial practice enacted a determinate reality of the project and the system failure, as an agential cut.

The rise of a competing agency of assessment in the Phase 2 development network could be observed during the increasing engagement of business experts and the brokers with the Olympia-online development. The ontological politics in this network, the inclusion of brokers and allocation of considerable resources to cater for their needs, and, in particular, the intra-actions among the Olympia team, the application 
software, business experts, and the brokers, produced sociomaterial practices that ultimately enacted the reality of Olympia-online success. These sociomaterial practices refer to the Phase 2 project and to the Olympia-online system embedded in brokers' work processes of selling insurance products to clients and transacting business with Olympia. The intra-actions in the Phase 2 project (examined in-depth earlier) ensured that the brokers engaged with and enacted Olympia-online as a high quality system, which subsequently attracted large numbers of brokers and became a market success. The agency of assessment in this network thus performed an agential cut that made the Olympia-online project and the system a determinate success. In this case too, the agency of assessment enacted both the objects of assessment, the Olympia-online project and the system, and their assessments.

The rise of different agencies of assessment and the enactment of different, and mutually competing, realities of the Olympiaonline project and system success could, as we have seen in the literature, be explained by different narratives, interpretations, and social constructions by different stakeholders or relevant social groups (Bartis and Mitev 2008; Fincham 2002; Wilson and Howcroft 2005). In this case, we would assume plurality of views and assessments of a single IS project and system reality. Plurality assumes the existence of a single object that is observed, perceived, and interpreted differently by different social groups (Law 2004; Mol 1999). But there was no such a thing as a single Olympia-online project or a single Olympia-online system that existed, outside of relations in actor-networks. Instead, we found a multiplicity of both the Olympia-online project and the Olympiaonline system: one enacted in the Steering Committee actornetwork and the other in the Olympia-online Phase 2 project actor-network. Multiplicity implies multiple realities that are

done and enacted rather than observed. Rather than being seen by a diversity of watching eyes while itself remaining untouched in the centre, reality is manipulated by means of various tools in the course of a diversity of practices (Mol 1999, p. 77).

Expressed differently, the reasons for multiple IS realities and competing assessments are not epistemological but rather ontological. As the Olympia-online actor-network decomposed into two different networks, different ontological politics, inclusions and exclusions, and intra-actions in these two actor-networks performed different sociomaterial practices and enabled different agencies of assessment to arise and thus enact multiple IS realities and competing assessments. The agencies of assessment enacted both the object and the outcome of the assessments.
The analysis and discussion of the Olympia-online case allowed us to theorize and illustrate the performative perspective on IS success. The discussion shows that the success of information systems is inherently indeterminate. This does not mean that researchers or practitioners are incapable of assessing them. This rather suggests that IS success is indeterminate unless it becomes determinate by virtue of the agency of assessment resulting from ontological politics and intra-actions in an IS project actor-network. As we have seen, an agency of assessment enacted both the object of assessment, what an information system is, and the outcome, its success or failure, as an agential cut in an actor-network at a particular point in time. In this way, the inherent indeterminacy of IS success is locally and temporally resolved: IS success becomes determinable and determinate. This also implies that an information system or IS project enacted in different sociomaterial practices may in principle produce multiple and competing realities of success and failure.

\section{Conclusion}

In this paper, we provide a theoretical and empirical argument for a performative perspective on IS success, and thereby contribute to the emerging sociomaterial literature (Orlikowski and Scott 2008; Suchman 2007). Based on a relational ontology - that everything exists in relations - the performative perspective endorses a particular view of IS success or failure as sociomaterial accomplishments performed in and by heterogeneous and continually reconfiguring IS project actornetworks. Like any perspective, it is both limited to and productive of the specific nature of the phenomenon studied. It is thus important to recognize that the performative perspective makes IS success and failure intelligible in a particular way. To appreciate its value and contribution, it is also important to highlight what kind of novel insights into IS assessments are enabled by the performative perspective and whether or how they matter. In this concluding section, we summarize particular insights provided by the performative perspective and its contributions to understanding IS success and how multiple and competing assessments come about. While doing this, we also reflect on its limitations and suggest some promising avenues for further research.

First, by conceiving of IS projects as actor-networks that enroll and mobilize heterogeneous actors - managers, technologies, IS developers, methodologies, business cases, users, committees, project documents, reports, and others-to develop and implement information systems, the performative perspective adopts a particular sociomaterial worldview that reveals some and not other events, processes, or mechanisms relevant for IS projects and their success. For instance, it 
focuses on IS project actor-networks within which actors define and negotiate a space, a scope, a period of time, and resources (Law and Callon 1997) as well as "a common political agenda and field of action" (McMaster and Wastell 2005, p. 180) for the development and implementation of an information system. It is the IS project actor-networks and their shifting sociomaterial practices, within which information systems are enacted and reenacted, and in which these enactments produce multiple and potentially competing realities of IS success or failure. By seeing IS assessments as relational effects produced together with the objects of assessments - information systems and IS projects-the performative perspective is thus fundamentally nonrepresentational. As such, it proposes that IS project actornetworks, their configurations and reconfigurations, are of central importance for investigating, questioning, and understanding IS success and failure in practice.

Second, and following from the above, the performative perspective reveals that success or failure of information systems and IS projects are inherently indeterminate, as our empirical study illustrates. This is due to the dynamic and emergent nature of IS project actor-networks with the possibility of alternative reconfigurations and performance of different realities always present (Law 2004; Mol 1999). As ontological politics reconfigures an IS actor-network, performing particular inclusions and exclusions, and thereby enabling specific intra-actions, the production of IS success may become temporally determinable and determinate. This happens when an agency of assessment emerges through specific intra-actions in an IS project actor-network, producing sociomaterial practices that enact, as an agential cut, both an information system as the object of assessment and its assessment. In other words, the IS project and the implemented system as objects of assessment are not given and fixed but are performed by the agencies of assessments, together with their assessment. It is also important to note that an agency of assessment is inextricably tied to the dynamics of sociomaterial arrangements in an IS project actor-network rather than inherent in specific network elements. The theoretical propositions - that IS success or failure are inherently indeterminate and that they become temporally determinate by agential cuts preformed by particular agencies of assessment emerging in IS project actornetworks - challenge the conventional wisdom of representational views of IS assessment. Further case studies are called for to scrutinize these propositions and investigate their relevance in different contexts and situations.

Third, through the analysis of the reconfigurations of the Olympia-online project actor-networks, the paper explains and illustrates how multiple realities of an IS success and failure can be produced concurrently. When an IS project actor-network decomposes into two or more actor-networks and these networks become more disconnected, chances are the realities produced by these networks could be multiple and not necessarily coherent. While multiple and noncoherent IS project realities may cohabitate and stimulate development, conflicting and competing realities may be disturbing and jeopardize further development, as was the case with the Olympia-online project. This insight draws attention to important questions regarding the multiple and conflicting IS realities that the performative perspective can help explore and address.

The performative perspective provides new conceptual resources to research and understand multiple enactments of information systems and potentially conflicting IS realities by exposing ontological politics at work in their production. While it may seem that ontological politics is our destiny, numerous lessons from the Olympia case teach us that there were options to make different choices along the way and to reenact realities differently (Law 2004; Mol 1999). Furthermore, paying attention to the ways agencies of assessment emerge in different actor-networks - resulting from different ontological politics and intra-acting-helps reveal how multiple IS realities are performed in different networks. It also reveals often hidden capacities for action to perform realities differently. The implications are significant: the multiplicity of IS realities in different IS project actornetworks becomes transparent and open for scrutiny and intervention. As a result, the performative perspective offers new avenues for researching, understanding, and living with a multiplicity of IS realities and assessments and also, and importantly, opens new research questions about conflicting realities that threaten IS projects and how to deal with them.

Fourth, the performative framing of IS success allows us to broaden the view and make intelligible the different framings from the literature. By effacing the complex and contingent production of success or failure within emergent and reconfiguring actor-networks and by focusing only on the outcomes - the final verdict of success or failure of an information system and an IS project - they appear as discrete and determinate states that are objectively measured (represented) as assumed by the objective/rational framing (DeLone and McLean 2003; Dibbern et al. 2004; Flowers 1996; Urbach et al. 2008; Wang 2008). On the other hand, by focusing on the sensemaking, interpretive, and political processes of information systems and IS project assessments, one could reveal narratives and interpretations, that is, subjective representations, of success and failure by different stakeholders or relevant social groups as suggested by the subjective/political framing (Bartis and Mitev 2008; Fincham 2002; Klecun and 
Cornford 2005; Mitev 2000; Sauer 1993). It is important to note that the performative framing of IS success is not proposed instead of the other two; rather, it extends existing knowledge by providing a conceptual apparatus that broadens the vision and enables understanding of specific conditions that make intelligible the different framings of IS success. For instance, it allows us to make visible the selected aspects of assessment, outcome, and process that these framings focus on and those they exclude. It also enables us to examine the creation of what is assumed to comprise relevant social groups, their particular inclusions and exclusions, and explain how they come to construct particular narratives and interpretations of IS success.

Fifth, the performative framing of IS success has some important practical implications. How an IS project is enacted in practice and how IS success or failure are performed are not just interesting research questions. They are highly pertinent practical questions. By making the familiar processes of IS assessment unfamiliar, that is, seeing them as inherently indeterminate, the performative perspective on IS success sensitizes managers, both IS and others, to focus their attention on the reconfiguration of relations in IS projects and the workings of ontological politics and how they bring about a particular agency of assessment that temporally enacts an agential cut: determinate IS assessments together with the IS as the object of assessment. However, to make the performative perspective applicable in practice, its concepts and the language of project actor-networks, ontological politics, intraactions, agency of assessment and agential cuts, need to be translated into the mundane vocabulary of IS practitioners. While these concepts are derived from real-life contexts, the language of performative perspective presents a barrier to their use in practice. The translation, though, is not a straightforward and linear process. A cooperative effort by practitioners and researchers is required to instantiate and practically enact the conceptual apparatus of the performative perspective in existing IS projects, and then observe what they do and how they make actors see and act differently.

Finally, we suggest that the performative perspective might help us change conversations on IS success from being focused on questions of epistemology (how we find out whether an information system is a success or failure) to questions of ontology (how an information system and its success or failure come into being). Changing the conversations may have important implications for changing practices of IS assessments and the ways IS failure rates are reported. This is timely and may help us explain why companies worldwide are not deterred by the reported high IS failure rates while increasing IS investments and their expectations for information systems to support innovation and growth (McKinsey \& Company 2011).

\section{Acknowledgments}

We are thankful to the review team for their constructive comments and criticism on earlier versions of this paper. We are in particular grateful to the senior editor, Ola Henfridsson, for his invaluable assistance and skillful guidance throughout the review process. In developing our paper, we also benefitted from comments received from colleagues at ACIS 2006, ISD 2006, and IFIP WG8.6 in 2013 when we presented parts of our research.

\section{References}

Alcadipani, R., and Hassard , J. 2010. "Actor-Network Theory, Organizations and Critique: Towards a Politics of Organizing," Organization (17:4), pp. 419-435.

Barad, K. 2003. "Posthumanist Performativity: Toward an Understanding of How Matter Comes to Matter," Signs: Journal of Women in Culture and Society (28:3), pp. 801-831.

Barad, K. 2007. Meeting the Universe Halfway: Quantum Physics and the Entanglement of Matter and Meaning, Durham, NC: Duke University Press.

Bartis, E., and Mitev, N. 2008. "A Multiple Narrative Approach to Information System Failure: A Successful System that Failed," European Journal of Information Systems (17), pp. 112-124.

Biehl, M. 2007. "Success Factors for Implementing Global Information Systems," Communications of the ACM(50:1), pp. 53-58.

Bloch, M., Blumberg, S., and Laartz, J. 2012. "Delivering LargeScale IT Projects on Time, on Budget, and on Value," McKinsey \& Company (http://www.mckinseyquarterly.com/ Delivering_largescale_IT_projects_on_time_on_budget_and on_value_3026; accessed October 2012).

Briggs, R. O., De Vreede, G.-J., Nunamaker, J. F., and Sprague, R. H. Jr. 2003. "Special Issue: Information Systems Success," Journal of Management Information Systems (19:4), pp. 5-8.

Bruni, A. 2005. "Shadowing Software and Clinical Records: On the Ethnography of Non-Humans and Heterogeneous Contexts," Organization (12:3), pp. 357-378.

Callon, M. 1986. "Some Elements of a Sociology of Translation: Domestication of the Scallops and the Fisherman of St. Brieuc Bay," in Power, Action and Belief: A New Sociology of Knowledge?, J. Law (ed.), London: Routledge and Kegan Paul, pp. 196-233.

Callon, M. 1991. "Techno-Economic Networks and Irreversibility," in A Sociology of Monsters: Essays on Power, Technology and Domination, J. Law (ed.), London: Routledge, pp. 132-164.

Cobb, M. 1996. "Unfinished Voyages: A Follow-Up to the CHAOS Report, The Standish Group" (http://www.umflint.edu/ $\sim$ weli/courses/bus381/assignment/vo.pdf).

Currie, W. 1997. "Computerising the Stock Exchange: A Comparison of Two Information Systems," New Technology, Work and Employment (12:2), pp. 75-83.

DeLone, W. H., and McLean, E. R. 1992. "Information System Success: The Quest for the Dependent Variable," Information Systems Research (3:1), pp. 60-95. 
DeLone, W. H., and McLean, E. R. 2003. "The DeLone and McLean Model of Information System Success: A Ten Year Update," Journal of Management Information Systems (19:4), pp. 9-30.

Dibbern, J., Goles, T., and Hirschheim, R. 2004. "Information Systems Outsourcing: a Survey and Analysis of Literature," The Data Base for Advances in Information Systems (35), pp. 6-102.

Doherty, N. F., Ashurst, C., and Peppard, J. 2011. "Factors Affecting the Successful Realization of Benefits from System Development Projects: Findings from Three Case Studies," Journal of Information Technology, pp.1-16.

El Emam, K., and Koru, A. G. 2008. "A Replicated Survey of IT Software Project Failure," IEEE Software (8), pp. 84-90.

Ewusi-Mensah, K., and Przasnyski, Z. H. 1994. "Factors Contributing to the Abandonment of Information Systems Development Projects," Journal of Information Technology (9:3), pp. 185-202.

Fincham, R. 2002. "Narratives of Success and Failure in Systems Development," British Journal of Management (13:1), pp. 1-14.

Flowers, S. 1996. Software Failure: Management Failure: Amazing Stories and Cautionary Tales, Chichester: John Wiley $\&$ Sons.

He, J., and King, W. R. 2008. "The Role of User Participation in Information Systems Development: Implications from Metaanalysis," Journal of Management Information Systems (25:1), pp. 301-331.

Hirschheim, R., and Smithson, S. 1988. "A Critical Analysis of Information Systems Evaluation," in Information Systems Assessment: Issues and Challenges, N. Bjørn-Andersen and G. Davis (eds.), Amsterdam: North Holland, pp. 17-37.

Holmström, J., and Sawyer, S. 2011. "Requirements Engineering Blinders: Exploring Information Systems Developers' BlackBoxing of the Emergent Character of Requirements," European Journal of Information Systems (20), pp. 34-47

Howcroft, D., Mitev, N., and Wilson, M. 2004. "What We May Learn from the Social Shaping of Technology Approach," in Social Theory and Philosophy for Information Systems, J. Mingers and L. Willcocks (eds.), Chichester: John Willey \& Sons, pp. 329-371.

Introna, L. D., and Whittaker, L. 2003. "The Phenomenology of Information Systems Evaluation: Overcoming the Subjective/ Objective Dualism," in Global and Organizational Discourse about Information Technology, E. H. Wynn, E. A. Whitley, M. D. Myers, and J. I. DeGross (eds.), Boston: Kluwer Academic Publishers, pp. 155-175.

Jones, S., and Hughes, J. 2001. "Understanding IS Evaluation as a Complex Social Process: A Case Study of a UK Local Authority," European Journal of Information Systems (10), pp. 189-203.

Kuhn, T. S. 1962. The Structure of Scientific Revolutions, Chicago: Chicago University Press.

Klecun, E., and Cornford, T. 2005. "A Critical Approach to Evaluation," European Journal of Information Systems (14), pp. 229-243.

Latour, B. 1987. Science in Action: How to Follow Scientists and Engineers through Society, Cambridge, MA: Harvard University Press.
Latour, B. 1992. "Where Are the Missing Masses? Sociology of a Few Mundane Artefacts," in Shaping Technology, Building Society: Studies of Sociotechnical Change, W. Bijker and J. Law (eds.), Cambridge, MA: MIT Press.

Latour, B. 2005. Reassembling the Social: An Introduction to Actor-Network Theory, Oxford, UK: Oxford University Press.

Law, J. 1988. "The Anatomy of Socio-Technical Struggle: The Design of the TSR2," in Technology and Social Process, B. Elliott (ed.), Edinburgh: Edinburgh University Press, pp. 44-69.

Law, J. 1992. "Notes on the Theory of the Actor-Network: Ordering, Strategy and Heterogeneity," Systems Practice (5:4), pp. 379-393.

Law, J. 2004. After Method: Mess in Social Science Research, London: Routledge.

Law. J. 2008a. "On STS and Sociology," The Sociological Review (56:4), pp. 623-649.

Law, J. 2008b. "Actor-Network Theory and Material Semiotics," in The New Blackwell Companion to Social Theory ( $3^{\text {rd }}$ ed.), B. S. Turner (ed.), Oxford, UK: Blackwell Publishing, pp. 141-158.

Law, J., and Callon, M. 1997. "The Life and Death of an Aircraft; A Network Analysis of Technical Change," in Shaping Technology/Building Society: Studies in Sociotechnical Change, W. E. Bijker and J. Law (eds.), Cambridge, MA: MIT Press, pp. 21-52.

Lee, G., and Xia, W. 2005. "The Ability of Information Systems Development Project Teams to Respond to Business and Technology Changes: A Study of Flexibility Measures," European Journal of Information Systems (14), pp. 75-92.

Lyytinen, K., and Hirschheim, R. A. 1987. "Information Systems Failure: A Survey and Classification of the Empirical Literature," in Oxford Surveys in Information Technology, Volume 4, P. I. Zorkoczy (ed.), Oxford, UK: Oxford University Press, pp. 257-309.

MacKenzie, D., and Wajcman, J. (Eds.). 1985. The Social Shaping of Technology, Milton Keynes, UK: Open University Press.

McKinsey \& Company. 2011. "A Rising Role of IT: McKinsey Global Survey Results," McKinsey Quarterly, December (https://www.mckinseyquarterly.com/A_rising_role_for_IT_ McKinsey_Global_Survey_results_2900; accessed May 2012).

McMaster, T., and Wastell, D. 2005. "The Agency of Hybrids: Overcoming the Symmetrophobic Block," Scandinavian Journal of Information Systems (17:1), pp. 175-182.

Mitev, N. N. 2000. "Toward Social Constructivist Understanding of IS Success and Failure: Introducing a New Computerized Reservation System," in Proceedings of the $21^{\text {st }}$ International Conference on Information Systems, December 10-13, Brisbane, Australia. Paper 9 (http://aisel.aisnet.org/icis2000/9).

Mol, A. 1999. "Ontological Politics. A Word and Some Questions," in Actor Network Theory and After, J. Law and J. Hassard (eds.), Oxford, UK: Blackwell Publishing, pp. 74-89.

Mol, A. 2000. "Pathology and the Clinic: An Ethnographic Presentation of Two Atherosclerosis," in Living and Working with New Medical Technologies, M. Lock, A. Young, and A. Cambrosio (eds.), Cambridge, Cambridge University Press, pp. 82-102. 
Mol, A. 2002. The Body Multiple: Ontology in Medical Practice, Durham, NC: Duke University Press.

Myers, M. D. 1994. "A Disaster for Everyone to See: An Interpretive Analysis of a Failed IS Project," Accounting, Management, and Information Technologies (4:4), pp. 185-201.

Orlikowski, W. J. 2007. "Sociomaterial Practices: Exploring Technology at Work," Organization Studies (28:9), pp. 1435-1448.

Orlikowski, W. J. 2010. "The Sociomateriality of Organizational Life: Cosidering Technology in Management Research," Cambridge Journal of Economics (34:1), pp. 125-141.

Orlikowski, W. J., and Scott, S. V. 2008. "Sociomateriality: Challenging the Separation of Technology, Work and Organization," The Academy of Management Annals (2:1), pp. 433-474.

Petter, S., DeLone W., and McLean, E. 2008. "Measuring Information Systems Success: Models, Dimensions, Measures, and Interpretations," European Journal of Information Systems (17), pp. 236-263.

Pickering, A. 1993. "The Mangle of Practice, Agency and Emergence in the Sociology of Science," American Journal of Sociology (99:3), pp. 559-589.

Rai, A., Lang, S. S., and Welker, R. B. 2002. "Assessing the Validity of IS Success Models: An Empirical Test and Theoretical Analysis," Information Systems Research (13:1), pp. 50-69.

Ramiller, N. C., and Wagner, E. L., 2009. "The Element of Surprise: Appreciating the Unexpected in (and through) Actor Networks," Information Technology \& People (22:1), pp. 36-50.

Rouse, J. 1996. Engaging Science: How to Understand its Practices Philosophically, Ithaca, NY: Cornell University Press.

Remus, U., and Wiener, M. 2010. "A Multi-Method, Holistic Strategy for Researching Critical Success Factors in IT Projects," Information Systems Journal (20:1), pp. 25-52.

Sabherwal, R., Jeyaraj, A ., and Chowa, C. 2006. "Information System Success: Individual and Organizational Determinants," Management Science (52:12) pp. 1849-1864.

Sarker, S., Sarker, S., and Sidorova, A. 2006. "Understanding Business Process Change Failure: An Actor-Network Perspective," Journal of Management Information System (23:1), pp. 51-86.

Sauer, C. 1993. Why Information Systems Fail: A Case Study Approach, Henley-on-Thames, UK: Alfred Waller.

Sauer, C., and Davis, G. B. 2010. "Information Systems Failure," in Encyclopaedia of Library \& Information Sciences ( $3^{\text {rd }} \mathrm{ed}$.), K. J. Bates and M. N. Maack (eds.), New York: CRC Press, pp. 2643-2652.

Smithson, S., and Tsiavos, P. 2004. "Re-Constructing Information System Evaluation," in The Social Study of Information and Communication Technology: Innovation, Actors, and Contexts, C. Avgerou, C. Ciborra, and F. Land,(eds.), Oxford, UK: Oxford University Press, pp. 207-230.

Suchman, L. A. 2007. Human-Machine Reconfigurations: Plans and Situated Actions, Cambridge, UK: Cambridge University Press.

Truex, D. P., Baskerville, R. L., and Klein, H. K. 1999. "Growing Systems in Emergent Organizations," Communications of the $\operatorname{ACM}$ (42:8), pp. 117-123.
Urbach, N., Smolnik, S., and Riempp, G. 2008. "A Methodological Examination of Empirical Research on Information System Success: 2003-2007," in Proceedings of the 14 $4^{\text {th }}$ Americas Conference on Information Systems, Toronto, Canada.

Verbeek, P.-P. 2005. What Things Do: Philosophical Reflections on Technology, Agency and Design, University Park, PA: The Pennsylvania State University Press.

Walsham, G. 1995. "Interpretive Case Studies in IS Research: Nature and Method," European Journal of Information Systems (4), pp. 74-81.

Walsham, G. 1999. "Interpretive Evaluation Design for Information Systems," in Beyond the IT Productivity Paradox, L. Willcocks and S. Lester (eds.), Chichester, UK: John Wiley and Sons, pp. 363-380.

Walsham, G., and Sahay, S. 1999. "GIS for District-Level Administration in India: Problems and Opportunities," MIS Quarterly (23:1), pp. 39-65.

Wang, E. T. G., Shih, S.-P., Jiang, J. J., and Klein, G. 2008. "The Consistency among Facilitating Factors and ERP Implementation Success: A Holistic View of Fit, Journal of Systems and Software (81), pp. 1609-1621.

Wang, Y.-S. 2008. "Assessing E-Commerce Systems Success: A Respectification and Validation of the DeLone and McLean Model of IS Success," Information Systems Journal (18), pp. 529-557.

Wilson, M., and Howcroft, D. 2005. "Power, Politics and Persuasion in IS Evaluation: A Focus on 'Relevant Social Groups', The Journal of Strategic Information Systems (14:1), pp. 17-43.

\section{About the Authors}

Dubravka Cecez-Kecmanovic is a professor of Information Systems in the School of Information Systems, Technology and Management in the Australian School of Business at the University of New South Wales. Her research and teaching interests include theoretical and methodological developments in understanding information, information technologies, information systems, and organizing. Her work has been published in Information Systems Journal, European Journal of Information Systems, Information Technology \& People, Journal of Information Technology, Decision Support Systems, Information \& Management, International Journal of Global Information Technology Management, International Journal of Actor Network Theory, and Technological Innovation, among others. She currently serves as a senior editor for Journal of AIS and an associate editor for Information Systems Journal.

Karlheinz Kautz is a professor of IT Management and Innovation in the School of Information Systems and Technology at the University of Wollongong. His research interests are in the design, development, adoption, and diffusion of information systems and information technology innovations, information system development methodologies, and the impact of IT. He has published widely in these areas. Karl is a founding member the IFIP TC 8 WG 8.6 on 
the adoption and diffusion of IT innovations. He currently serves as a senior editor for Journal of Information Technology, as an associate editor for Journal of the AIS, and the debate editor for Communications of the AIS.

Rebecca Abrahall completed an honours degree in Information Systems and continued her research at the School of Information
Systems, Technology and Management (SISTM), University of New South Wales, as a research assistant. Her research focused on information systems development and evaluation and the application of actor-network theory. While she now pursues a career in medicine (completing a Bachelor of Medicine/Bachelor of Surgery from the University of Sydney in 2011), Rebecca continues her research association with SISTM.

\section{Appendix}

\begin{tabular}{|c|c|c|c|}
\hline Position & Pseudonym & $\begin{array}{l}\text { Interview/ } \\
\text { Informal } \\
\text { Discussion }\end{array}$ & $\begin{array}{l}\text { Role in the Olympia-online Development and Implementation } \\
\text { Project }\end{array}$ \\
\hline \multicolumn{4}{|c|}{ Information Services } \\
\hline $\mathrm{ClO}$ & Jiashu & Interview & $\begin{array}{l}\text { Senior executive in the Information Services Department who } \\
\text { served on the Phase } 2 \text { Steering Committee }\end{array}$ \\
\hline Head of IS for GI & Henry & $\begin{array}{l}\text { Informal } \\
\text { discussion }\end{array}$ & $\begin{array}{l}\text { Olympia manager reporting to } \mathrm{ClO} \text { responsible for IS development } \\
\text { for General Insurance (GI) }\end{array}$ \\
\hline $\begin{array}{l}\text { Head Architect - } \\
\text { Senior Architect } \\
\text { from Information } \\
\text { Services }\end{array}$ & George & $\begin{array}{l}\text { Interview and } \\
\text { informal } \\
\text { discussions }\end{array}$ & $\begin{array}{l}\text { Olympia architect for Phase } 1 \text { and Phase } 2 \text { of the project; provided } \\
\text { critical data about the history of the project and documents relevant } \\
\text { for understanding the Phase } 1 \text { development project; provided also } \\
\text { insights into current developments and emerging situations }\end{array}$ \\
\hline HightTech Architect & Sunil & $\begin{array}{l}\text { Interview and } \\
\text { informal } \\
\text { discussions }\end{array}$ & HighTech architect for Phase 2 of the project \\
\hline $\begin{array}{l}\text { Senior Business } \\
\text { Analyst }\end{array}$ & Alan & $\begin{array}{l}\text { Interview and } \\
\text { informal } \\
\text { discussions }\end{array}$ & $\begin{array}{l}\text { Formerly an employee of the consulting company HighTech } \\
\text { contracted to develop the Phase } 1 \text { system; becomes a permanent } \\
\text { employee of Olympia in Phase } 2 \text { of the project and continues as a } \\
\text { member of the Phase } 2 \text { system support team in production }\end{array}$ \\
\hline $\begin{array}{l}\text { Application } \\
\text { Developer }\end{array}$ & Patrick & Interview & $\begin{array}{l}\text { Application developer hired by Olympia as a permanent to work on } \\
\text { the Phase } 2 \text { project }\end{array}$ \\
\hline $\begin{array}{l}\text { Application } \\
\text { Developer }\end{array}$ & Ron & $\begin{array}{l}\text { Interview and } \\
\text { informal } \\
\text { discussions }\end{array}$ & $\begin{array}{l}\text { Hired by Olympia as a permanent employee to work on the Phase } \\
2 \text { project; continued as a member of the Phase } 2 \text { system support } \\
\text { team in production }\end{array}$ \\
\hline $\begin{array}{l}\text { Mainframe } \\
\text { Developer }\end{array}$ & Marie & $\begin{array}{l}\text { Informal } \\
\text { discussion }\end{array}$ & $\begin{array}{l}\text { Permanent employee of Olympia responsible for parts of } \\
\text { application software developed on the mainframe }\end{array}$ \\
\hline $\begin{array}{l}\text { Delivery Control } \\
\text { Manager }\end{array}$ & Khim & $\begin{array}{l}\text { Informal } \\
\text { discussion }\end{array}$ & $\begin{array}{l}\text { Olympia employee responsible for Phase } 2 \text { development and } \\
\text { migration from Phase } 1 \text { to Phase } 2 \text { system }\end{array}$ \\
\hline IS Project Manager & Sebastian & $\begin{array}{l}\text { Informal } \\
\text { discussion }\end{array}$ & $\begin{array}{l}\text { Hired by Olympia as a permanent employee to work on the Phase } \\
2 \text { project responsible to deliver the Olympia-Online system on time } \\
\text { and on budget; member of the Steering Committee }\end{array}$ \\
\hline $\begin{array}{l}\text { Data Migration } \\
\text { Developer }\end{array}$ & Robert & Interview & $\begin{array}{l}\text { Hired by Olympia as a permanent employee to work on Phase } 2 \text { of } \\
\text { the project, responsible for migrating existing customer data from } \\
\text { the Phase } 1 \text { system to the new Phase } 2 \text { system; continues as a } \\
\text { member of the Phase } 2 \text { support team in production }\end{array}$ \\
\hline Test Team Leader & Gareth & Interview & $\begin{array}{l}\text { Hired as a contractor to work on the Phase } 2 \text { project; continued as } \\
\text { a member of the Phase } 2 \text { system support team in production }\end{array}$ \\
\hline $\begin{array}{l}\text { Members of the } \\
\text { testing team }\end{array}$ & $\begin{array}{l}\text { Anna, Mark, } \\
\text { and Phil }\end{array}$ & $\begin{array}{l}\text { Informal } \\
\text { discussions }\end{array}$ & External contractors involved in testing in Phase 1 and 2 \\
\hline
\end{tabular}


Table A1. Human Actors Involved in Interviewees and Informal Discussions During Phase 2 Development and Implementation (Continued)

\begin{tabular}{|c|c|c|c|}
\hline Position & Pseudonym & $\begin{array}{l}\text { Interview/ } \\
\text { Informal } \\
\text { Discussion }\end{array}$ & $\begin{array}{l}\text { Role in the Olympia-online Development and Implementation } \\
\text { Project }\end{array}$ \\
\hline \multicolumn{4}{|l|}{ General Insurance } \\
\hline Head of GI & Roger & $\begin{array}{l}\text { Informal } \\
\text { discussion }\end{array}$ & $\begin{array}{l}\text { Top manager, one of initiators of the Olympia-Online development } \\
\text { project }\end{array}$ \\
\hline $\begin{array}{l}\text { Business Expert - } \\
\text { Liaising with brokers }\end{array}$ & Chris & $\begin{array}{l}\text { Interview and } \\
\text { informal } \\
\text { discussions }\end{array}$ & $\begin{array}{l}\text { Olympia business expert liaising with a broker community in Phase } \\
1 \text { and Phase } 2 \text { of the project. }\end{array}$ \\
\hline $\begin{array}{l}\text { Business Expert - } \\
\text { Underwriting }\end{array}$ & Roland & Interview & $\begin{array}{l}\text { The Olympia underwriting business expert from Phase } 1 \text { and } \\
\text { Phase } 2 \text { of the project }\end{array}$ \\
\hline $\begin{array}{l}\text { Senior Gl business } \\
\text { manager }\end{array}$ & Rene & Interview & $\begin{array}{l}\text { One of the top GI managers responsible for and involved in } \\
\text { Olympia-online project in both phases }\end{array}$ \\
\hline \multicolumn{4}{|c|}{ Strategy and Planning Division } \\
\hline $\begin{array}{l}\text { Head of Strategy } \\
\text { and Planning }\end{array}$ & Paul & $\begin{array}{l}\text { Informal } \\
\text { discussion }\end{array}$ & $\begin{array}{l}\text { Top manager, one of initiators and sponsors of the Olympia-Online } \\
\text { development project }\end{array}$ \\
\hline $\begin{array}{l}\text { Business Project } \\
\text { Manager }\end{array}$ & Stuart & Interview & $\begin{array}{l}\text { Olympia business project manager for Phase } 2 \text { of the project and a } \\
\text { member of the Steering Committee }\end{array}$ \\
\hline $\begin{array}{l}\text { Olympia's national } \\
\text { e-commerce } \\
\text { manager }\end{array}$ & John & Interview & $\begin{array}{l}\text { Closely linked to Olympia top management, one of initiators of the } \\
\text { Olympia-Online development project }\end{array}$ \\
\hline Brokers & $\begin{array}{l}\text { Tim and } \\
\text { Ernest }\end{array}$ & $\begin{array}{l}\text { Informal } \\
\text { discussions }\end{array}$ & $\begin{array}{l}\text { Early users of Olympia-online who worked closely with Business } \\
\text { Expert (liaising with brokers) during testing and improvements in } \\
\text { Phase } 2\end{array}$ \\
\hline
\end{tabular}

\section{Table A2. Olympia-online Documents}

\begin{tabular}{|l|l|}
\hline \multicolumn{1}{|c|}{ Phase 1 Documents } & \multicolumn{1}{c|}{ Phase 2 Documents } \\
\hline Business plan & Phase 2 development document \\
\hline Contract with HighTech & Renewed contract with HightTech \\
\hline Business case and scope document & New scope document \\
\hline Business information requirements document & Business information requirements document \\
\hline Emperor licence document & Emperor licence document \\
\hline Change requests (14) & Change requests (26) \\
\hline Test plans (3) & Test plans (5) \\
\hline Test cases (23) & Test cases (38) \\
\hline Meeting minutes (27) & Meeting minutes (35) \\
\hline Project reports (3) & Project reports (12) \\
\hline
\end{tabular}

\section{Table A3. Key Technologies Involved in the Olympia-online Development Project}

\section{Key technologies}

IT architecture

Mainframe resources

Mainframe based e-commerce platform BrokerLine

Web-based e-business platform Horizon

Rule-based engine Emperor

Olympia-online application software

Interface designs and programs 
Copyright of MIS Quarterly is the property of MIS Quarterly \& The Society for Information Management and its content may not be copied or emailed to multiple sites or posted to a

listserv without the copyright holder's express written permission. However, users may print, download, or email articles for individual use. 